\title{
PRE-COLUMBIAN JADEITE AXES FROM ANTIGUA, WEST INDIES: DESCRIPTION AND POSSIBLE SOURCES
}

\author{
GEORGE E. HARLOW \\ Department of Earth and Planetary Sciences, American Museum of Natural History, \\ Central Park West at 79th St., New York, NY 10024, U.S.A. \\ A. REG MURPHY \\ Museum of Antigua and Barbuda, P. O. Box 312, St John's, Antigua, West Indies \\ DAVID J. HOZJAN \\ Overburden Drilling Management Ltd. \\ 107-15 Capella Court, Nepean, Ontario K2E 7X1, Canada \\ Christy N. de MILLE \\ Department of Archaeology, University of Calgary, Calgary, Alberta T2N 1N4, Canada \\ ALFRED A. LEVINSON ${ }^{1}$ \\ Department of Geology and Geophysics, University of Calgary, \\ Calgary, Alberta T2N 1N4, Canada
}

Accepted for publication in the Canadian Mineralogist for $~$ April, 2006

§ E-mail address: gharlow@amnh.org

1 Deceased December 11, 2005 


\begin{abstract}
Excavation of ornamental and gem materials from workshop sites on the island of Antigua, West Indies, also uncovered jade celts (axe forms) and fragments thereof. All are jadeite jades (jadeitite), like jades from Mesoamerica. The Antigua sites date to the Saladoid period (ca. 250500 AD), roughly equivalent to the Early Classic period for Mesoamerican cultures, and reveal “jades" used in a context - decorative celt - well developed by Mesoamericans some $3100 \mathrm{~km}$ to the West. Ten of these jade artifacts were examined by a combination of mineralogical and petrographic techniques to determine their mineral constituents, mineral compositions and petrographic textures and place them in a context of possible sources among worldwide sources of jadeite jade. The common assemblage for six artifacts studied as polished sections include jadeite, omphacite, albite, a white-tan mica, quartz, zoisite/clinozoisite and titanite, with the exception of one artifact lacking albite and quartz, and one lacking mica. Allanite was found in the cores of zoisites in two jades, and glaucophane and lawsonite, each, were observed in single jades. The other four jades, which could not be studied as well, appear to contain comparable assemblages. Conspicuous among the Antigua jades is the textural setting of quartz, a phase absent from jadeitite from most sources worldwide. Quartz exists either as a secondary matrix phase around corroded jadeite grains (tiny omphacite grains in quartz decorate the boundaries of the jadeite) or as inclusions in jadeite associated with smaller omphacite regions. In comparison with jadeitite from $\sim 12$ described occurrences worldwide, only jadeitite from south of the Motagua fault zone (MFZ) in Guatemala regularly contain the appropriate assemblage including white mica and quartz. Moreover, glaucophane and lawsonite have also been observed in jadeitite from this source, and textures are also highly similar. However, differences include
\end{abstract}


absence of zoisite/clinozoisite and paragonite plus some divergences in pyroxene compositions in Guatemalan jadeitite from south of MFZ compared to Antigua jades. Although Guatemala is a reasonable source for the Antigua jades, as-yet unknown sources in similar geological terrain (serpentinite-matrix mélange) on Cuba, Hispaniola or Jamaica cannot be ruled out.

KEYWORDS: jade, jadeitite, Antigua, archaeomaterials, Caribbean geology

\section{Introduction}

New World jade is a jadeite-rich rock or jadeitite, an extremely durable and, in cases, a most beautiful stone, highly esteemed by many Mesoamerican peoples over a span of two millennia prior to "contact" with Europeans. In fact, the term "jade" derives from the chronicles of the Conquest of Mexico and New Spain by such as Nicolas Monardes (1580) with subsequent confusion of terms with a similar tool-stone, nephrite (a tough tremolite-actinolite rock with a felted texture of microscopic crystals) from China (see Foshag \& Leslie, 1955; Foshag, 1957). The term 'jade' is used for both nephrite and jadeitite, which causes confusion unless a modifier is added, as with jadeite jade and nephrite jade. The origin, that is, the geologic source, of Mesoamerican jadeitite has been a topic of great debate up to the present time, although the jadeitite samples found within serpentinite-matrix mélanges on either side of the Motagua fault zone of central Guatemala (Fig. 1) span the characteristics observed in Mesoamerican artifacts studied to date (see Harlow, 1993, 1994; Seitz et al., 2001; Taube et al., 2004).

Archaeological excavation of ornamental and gem materials from workshop sites on the island of Antigua, West Indies (Murphy 1999; Murphy et al., 2000) also uncovered a number of jadeite jade celts (small axe-shaped forms) and fragments thereof (Fig. 2). The sites date to the 
Saladoid period (ca. 250-500 AD), roughly the Early Classic period for Mesoamerican cultures, and reveal "jades" used in a context - decorative celt - well developed by Mesoamericans some $3100 \mathrm{~km}$ to the West. Although ground-stone technology is documented in the eastern Caribbean, documented jades are rare and usually nephrite. For example, two nephrite pendants were identified among more than 600 gem-related objects excavated on Antigua (Murphy et al., 2000). With respect to jadeite, Taino (post $700 \mathrm{CE}$ ) jades from the Greater Antilles have been mentioned, as well as a jadeite jade attributed to Jamaica (Easby, 1991). No geological sources of jadeitite or nephrite, the rocks used as jade worldwide, have been verified in the Caribbean islands, although jadeitite has been attributed (anecdotally) to sources among blueschist/eclogite/serpentinite terrains on Cuba (Iturralde Vinent, personal communication 2002) and Hispaniola (see below), and Rodriguez (1991) suggests a source in southwestern Puerto Rico along the Guanajibo River. All of these potential sources are much closer to Antigua than Guatemala; consequently, study of these Antigua jadeite jades in comparison to jadeitite from known sources may reveal both geologically and archaeologically important information. Nephrite objects from the islands of the eastern Caribbean have been ascribed to sources in South America (Guyana, Brazil and Venezuela), based on Saladoid origins from that continent (Cody, 1991), so analysis of jadeitite objects and potential sources provides additional data for constructing transport models.

The focus here is to describe the jadeitite jades discovered in the Saladoid workshops of Antigua, West Indies and compare them with known sources so as to evaluate the possible geographic origin of the jadeitite jade(s).

\section{Background on Jadeite Jade Studies}


In this study, 10 objects ultimately recognized as jadeite jade, roughly $30 \%$ of this type recovered, were selected as suitable for partially destructive analysis and examined by a combination of analytical techniques to determine their mineral constituents, mineral compositions and petrographic textures. Similar studies of Mesoamerican jade in comparison with jadeitite worldwide have shown that characteristic combinations of these data tend to be consistent with a single regional source and to exclude others (e.g., Harlow, 1993). Recent discoveries in Guatemala have expanded our knowledge of jadeitite sources; in particular, they indicate at least three distinct types, with two distinct Ar-Ar ages of formation or metamorphism in the mid- and late-Cretaceous (Harlow et al., 2003, 2004, Francis et al., 2005). The results of this study point in the direction of Guatemala as the source of the Antigua jade, but cannot as yet be considered definitive.

Jadeitite is a well-known but uncommon rock type that is found as tectonic inclusions in serpentinite mélanges; described occurrences are limited to about a dozen worldwide (Harlow \& Sorensen, 2005). The predominant minerals are jadeite (the pyroxene-group mineral having the formula $\mathrm{NaAlSi}_{2} \mathrm{O}_{6}$ ), omphacite (Omp), albite, white (white-to-tan) micas (phengitic muscovite, paragonite, phlogopite and/or preiswerkite), sodic to sodic-calcic amphibole, zoisite or clinozoisite, titanite and zircon; other sometimes distinctive minerals can be present in minor to trace amounts. Quartz is generally absent from jadeitite assemblages except among those from the lawsonite eclogite terrane in Guatemala (see below). Jadeitite is distinct from other occurrences of jadeite, as in glaucophane schist and rare jadeite whiteschist (e.g., Okay, 1997), in part because of the abundance of jadeite contained, its purity ( $>95 \%$ end-member), its coexistence, typically, with omphacite, the two pyroxenes being separated by a distinct compositional gap indicating a low-temperature formation (well below the crest of the solvus at $\sim 550^{\circ} \mathrm{C}$, Carpenter, 1980) and its extreme durability, which may be conferred by its origin. 
Textural evidence indicates that at all classic occurrences, jadeitite forms by direct crystallization from a hydrous fluid by emplacement as tectonized systems of veins in or as blocks in a serpentinite-matrix mélange (Sorensen \& Harlow, 1999; Harlow \& Sorensen, 2005). Albitite, approaching nearly monomineralic albite, and albite-muscovite rocks are commonly associated with jadeitite in the mélange setting.

Among the few occurrences of jadeitite, only two are described from the Americas. The major deposits in serpentinite bodies along the central Motagua Valley in Guatemala served as the source of jade for Middle America. The minor but well-described occurrence along Clear Creek, New Idria serpentinite, San Benito County, California (Coleman, 1961) does not appear to have been used as a source of jade. Jadeititic rocks from other parts of California and Mexico have been reported in the lapidary literature (e.g., Pashin, 1995; Castro \& Castro, 1979; Foshag, 1957), but observations by the first author find them to be selvages of jadeite-aegirine with a variety of other minerals and generally dissimilar to jadeitite, sensu stricto. Moreover, these other jadeite-bearing rocks typically show up as a rare cobble with uncertain geographic, let alone, geological origin. Nevertheless, data are here provided for a single example, from an unknown location in Baja California (provided by Mikhail Ostroumov, Universidad Michoacana de San Nicolás de Hidalgo), for comparison in this study. Potentially suitable geotectonic zones for jadeitite formation can be found along the tectonic boundaries of the Caribbean plate in Cuba, Hispaniola and Venezuela. Anecdotal "citings" of jadeite-rich rocks from Cuba exist (pers. comm., Manuel Iturralde Vinent), and a jadeite-quartz-albite rock from the Arroyo Sabana serpentinite-matrix mélange in the Dominican Republic was found by Grenville Draper (Draper \& Nagle, 1991), but the characteristics of this rock are grossly dissimilar to jadeitite or jadeite jades based on our observations. Jadeite (i.e., jadeitite) is reported as an archaeological material from Puerto Rico (Rodriguez, 1991), but there is no description in the geological literature. 


\section{Sample Preparation and Analytical Techniques}

Six fragment of the Antigua jade (those that are flat or sawn and have been made available for this partially destructive study) were ground to produce a flat surface and polished with diamond and alumina abrasives. At this point all six samples were imaged with a digital optical camera for reference of appearance. Polished pieces of jade were microscopically imaged using a Hitachi S-4700 Field Emission -Scanning Electron Microscope (SEM) with a back-scattered electron (BSE) detector and PGT-Imix energy-dispersive X-ray spectrometric (EDS) analyzer. Electron-microprobe analysis of these samples to determine concentrations of

the major constituent elements in the minerals (except O) was carried out using a Cameca SX100 instrument operating at $15 \mathrm{kV}$ and $10 \mathrm{nA}$ sample current, employing a point beam. Natural minerals were used as standards, and the PAP correction scheme according to Pouchou \& Pichoir (1991) was employed. Potential interferences between $\mathrm{Ba}(\mathrm{L} \alpha)$ and $\mathrm{Ti}(\mathrm{K} \alpha)$ were minimized by measuring X-ray counts on a PET crystal and background measured outside the window of both peaks; as long as concentrations are below $\sim 2 \mathrm{wt} \%$ of either, there are no overlaps that exceed the detection limit. For all elements the detection limits are $<0.01 \mathrm{wt} \%$ but "as measured" values are presented here. No post-processing correction was made for the effect of inferred $\mathrm{H}_{2} \mathrm{O}$ content.

Estimates of $\mathrm{Fe}^{2+}$ and $\mathrm{Fe}^{3+}$ were made using an algorithm similar in concept to that of Finger (1972) to calculate $\mathrm{Fe}^{3+}$ from total $\mathrm{Fe}$ in which cation charge must sum as close as possible to twice the number of oxygen atoms plus the number of univalent anions (e.g., 12 for six atoms of oxygen in pyroxene), with a maximum permissible sum of cations determined by the crystal's stoichiometry (e.g., four for pyroxene as above; vacancies in large cation sites are 
permissible). So, $\mathrm{Fe}^{3+}$ is converted from available measured $\mathrm{Fe}$ (assumed $\mathrm{Fe}^{2+}$ ) to attempt to account for deficient charge (or excess cations), extra $\mathrm{O}$ is added proportional to the $\mathrm{Fe}^{2+}$ converted to $\mathrm{Fe}^{3+}$, and iteration of the new $\mathrm{Fe}^{3+}$ and $\mathrm{O}$ values into the calculation until

convergence is achieved. Cations are then distributed in the several phases as $\mathrm{Si}$ and ${ }^{[4]} \mathrm{Al}$ into tetrahedral sites $(\mathrm{T})$; excess $\mathrm{Si}, \mathrm{Ti},{ }^{[6]} \mathrm{Al}, \mathrm{Fe}^{3+}, \mathrm{Fe}^{2+}, \mathrm{Mg}$ and in some cases $\mathrm{Ca}$ into 6-8 fold sites; and, $\mathrm{Na}, \mathrm{K}, \mathrm{Ba}$, and in others $\mathrm{Ca}$ into 8-12 fold sites, with cation sums noted as Sum $\mathrm{T}$, for tetrahedral cations, and Sum for all cations.

X-ray diffraction identification was carried out on some powdered samples of jade using a Bragg-Brentano diffractometer or on sub-millimeter fragments and sub-millimeter areas on jade surfaces using a Rigaku DMAX/Rapid microdiffraction system employing a $100 \mu \mathrm{m}$ monocapillary collimator and monochromatized $\mathrm{Cu} \mathrm{K} \alpha$ radiation. Samples were oscillated about a vertical axis $(\omega)$ and rotated about a $\varphi$-axis inclined at $45^{\circ}$ (fixed) from $\omega$ to obtain sufficient diffraction impingements on the cylindrical image plate with which to integrate as a representative diffractogram with well-defined peaks. Patterns were interpreted with Jade 7.0 (MDI) software; although Fe fluorescence degraded the patterns in some cases, the peaks were more than sufficient for assignment of $d$ values and phase identification.

\section{Workshop Sites and Artifact Descriptions}

Ten samples were examined from two workshop sites, Mill Reef (one sample) and Elliot's (nine samples), which are described in Murphy (1999) and Murphy et al. (2000). The visual characteristics of nine of the jades are briefly described in Table 1 and are imaged in Figure 2. 


\section{Mineralogy and Mineral Compositions}

Although in lapidary terms jadeitite typically contains more than 90 vol.\% jadeite, the complete mineral assemblage is generally specific as to source among the 12 described worldwide occurrences (Harlow \& Sorensen 2005; Harlow 1993) and are thus critical in source evaluation. The Antigua jade objects appear to be prestige objects or talismans (there is no sign of having been used as axes or choppers) and are relatively dark, opaque and variegated in color, typical of such celts, as opposed to the light or brilliant green colors and translucency of beads, ear spools and similar jewelry jades of Middle America. The darker, mottled color and textural variability of the Antigua celts reflect their being less predominantly jadeite (both as a mineral constituent and as an end-member component) as compared to lighter colored jade objects. The mineral constituents of the 10 jade objects studied are listed in Table 2.

The common mineral assemblage for the six samples studied in polished section (Table 2A) include jadeite, omphacite, albite, a white-tan mica, quartz, zoisite or clinozoisite and titanite, with only two exceptions: E78 appears to lack albite and quartz, and E93 lacks mica. Zircon is found as tiny grains $(<10 \mu \mathrm{m}$ across $)$ in four jade objects and could have been missed in the others. Allanite was found in the core of zoisite grains in two jade objects, and glaucophane was observed in a single artifact. The other four objects (Table 2B) could not be as well studied, even in thin-section, because many zones are of sub-30 $\mu \mathrm{m}$ grain size, less than the thickness of the section. In them, the assemblages appear to be comparable to the other six, mindful that tiny trace phases cannot be identified in thin section.

Textural relationships among the constituent phases are equally distinctive, as jadeitite bodies typically experience alteration during tectonic uplift. Conspicuous among the Antigua jade objects is the textural setting of quartz, a phase absent from jadeitite from most sources 
worldwide. Sample E150 contains quartz as a secondary matrix phase, with or without albite, surrounding irregular grains of jadeite, sometimes with quartz inclusions; these jadeite grains are partially encircled by narrow "reefs" of omphacite (Fig. 3A). In E92 with smaller areas of quartz, the omphacite "reef" encircles the quartz, although the actual juxtaposition of phases is the same (Fig. 3B); in addition, there are small irregular patches of omphacite and quartz along jadeite grain boundaries. A higher-magnification view of jade E152 shows quartz inclusions in jadeite associated with smaller regions of omphacite, even where irregular zones of omphacite exist apparently free of quartz (Fig. 3C). Artifact E78, which does not appear to contain quartz (or albite), does display an initial jadeite + omphacite stage of growth with abundant idioblastic titanite followed by veins of omphacite (Fig. 3D); note the complex zoning, evident by the varying levels of gray in omphacite and jadeite, which is a typical feature of many samples of jadeitite. Another, interesting textural feature is the mesh-textured titanite seen in artifact E92 (Fig. 3B). There is an apparent correlation of titanite abundance with that of omphacite, visible in E93, E150 and E78 (Fig. 3C).

Mineral compositions are an important aspect of jadeitite identity. Those minerals with adequate compositional range for comparison with those from jadeitite of known sources are the pyroxenes, jadeite and omphacite, and the micas. Pyroxene compositions are presented in terms of the molecular percentages of jadeite (Jd), diopside ( $\mathrm{Di}, \mathrm{CaMgSi}_{2} \mathrm{O}_{6}$ ), hedenbergite ( $\mathrm{Hd}$, $\left.\mathrm{CaFe}^{2+} \mathrm{Si}_{2} \mathrm{O}_{6}\right)$, aegirine $\left(\mathrm{NaFe}^{3+} \mathrm{Si}_{2} \mathrm{O}_{6}\right)$, enstatite $\left(\mathrm{Mg}_{2} \mathrm{Si}_{2} \mathrm{O}_{6}\right)$ and ferrosilite $\left(\mathrm{Fe}_{2} \mathrm{Si}_{2} \mathrm{O}_{6}\right)$. Of the six samples with compositional data, all but E92 share general pyroxene compositional traits, although each is somewhat different (Fig. 4): jadeite compositions ranging from $\mathrm{Jd}_{90}$ to $\mathrm{Jd}_{70}$, a modest omphacite gap, and omphacite ranging from $\mathrm{Jd}_{60}$ to $\mathrm{Jd}_{50}$ but also extending toward more diopsidic compositions of $\mathrm{Jd}_{50}$ to $\mathrm{Jd}_{<20}$. Among these, E78 has the lowest iron in jadeite, $\mathrm{Jd}_{84} \mathrm{Di}_{12} \mathrm{Ae}_{0-1} \mathrm{Hd}_{0-1}(\mathrm{En}+\mathrm{Fs})_{2-4}, \mathrm{E} 150$ is intermediate $\left(\mathrm{Jd}_{90} \mathrm{Di}_{1-8} \mathrm{Ae}_{0-7} \mathrm{Hd}_{0-3}(\mathrm{En}+\mathrm{Fs})_{1-4}\right)$ and $\mathrm{E} 152$ 
$\left(\mathrm{Jd}_{90},(\mathrm{En}+\mathrm{Fs})_{0-4}\right)$ and E153 $\left(\mathrm{Jd}_{94},(\mathrm{En}+\mathrm{Fs})_{1-3}\right)$ are about the same, $\mathrm{Ae}_{0-10}$ and $\mathrm{Hd}_{0-3}$. The omphacite in these is iron-rich in a somewhat rearranged order: $\mathrm{E} 150\left(\mathrm{Ae}_{2-10}, \mathrm{Hd}_{7-10}(\mathrm{En}+\mathrm{Fs})_{1-3}\right)$; E78 $\left(\mathrm{Ae}_{6-18}, \mathrm{Hd}_{2-11}(\mathrm{En}+\mathrm{Fs})_{0-3}\right) ; \mathrm{E} 152\left(\mathrm{Ae}_{7-28}, \mathrm{Hd}_{4-15},(\mathrm{En}+\mathrm{Fs})_{1-5}\right) ; \mathrm{E} 153\left(\mathrm{Ae}_{13}, \mathrm{Hd}_{8},(\mathrm{En}+\mathrm{Fs})_{1}\right)$ (an augitic pyroxene, $\mathrm{Jd}_{12}$, has $\mathrm{Hd}_{12-14}$ ). Artifact $\mathrm{E} 92$ is different, particularly for the Fe-rich trend of the omphacite toward aegirine augite. The most jadeite-rich compositions have $\mathrm{Jd}_{94-96} \mathrm{Ae}_{0-3} \mathrm{Hd}_{1}(\mathrm{En}+\mathrm{Fs})_{0-2}$ with a trajectory toward (Di+Hd) ${ }_{65} \mathrm{Ae}_{35}$ (Fig. 4). Omphacite, which occurs as small inclusions and atolls in quartz or as isolated grains, ranges from roughly $\mathrm{Jd}_{42} \mathrm{Di}_{25} \mathrm{Ae}_{21} \mathrm{Hd}_{10}$ toward very Fe-rich aegirine augite compositions, $\mathrm{Ae}_{43-56} \mathrm{Di}_{30-33} \mathrm{Jd}_{7-14} \mathrm{Hd}_{4-10}$. One of the ready interpretations from these pyroxene data is that the relative dark-green color of these artifacts is related to total iron, particularly in the omphacite, and the relative abundance of omphacite versus jadeite + quartz. Artifacts rich in omphacite (plus opaque phases like titanite) tend to be darker (e.g., E78, E152), and the mix of jadeite (and quartz) and omphacite produces the light-dark mottling or, in some cases, foliation where the distributions are aligned (most likely due to deformation and veining that are a part of jadeitite formation). The trend of pyroxene compositions, particularly obvious for E152 and E153, show considerable breadth, as seen in Figure 4, which can be interpreted as the change from initial growth of jadeite or jadeite + omphacite to omphacite and even sodic augite not in equilibrium with jadeite, which is typical for jadeitite (Harlow \& Sorensen, 2005). This interpretation is texturally supported with the calcic pyroxene veins, overgrowths and atolls shown in Figure 3.

Phengite $(\mathrm{Ph})$ compositions from artifacts E150 and E152 are given in Table 3 and plotted in Figure 5. The compositions are similar, with the main difference being the value of Si apfu (atoms per formula unit), those in E150 being slightly higher than in E152. Paragonite is relatively pure, with little Ca and very little $\mathrm{K}$, as demonstrated in the data for E153. Phengite in 
E78, paragonite in E92 and phlogopite in E152 and 153 did not yield high-quality analyses and are not presented in Table 3 .

Epidote-group minerals were found in all of the Antigua jade artifacts analyzed, except E93, which contains pumpellyite. It is not uncommon to find allanite at the core of clinozoisite grains. None were analyzed beyond energy dispersive examination, however, which showed them to be generally La-rich. In E153, grains are numerous and dominantly zoisite with some grains having Fe-enriched rims toward clinozoisite-like compositions (see Table 3) with up to $\sim 7.5 \mathrm{wt} \% \mathrm{Fe}_{2} \mathrm{O}_{3}$, whereas in $\mathrm{E} 152 \mathrm{Fe}_{2} \mathrm{O}_{3}$ varies from $\sim 7$ to $\sim 12 \mathrm{wt} \%$. The other jade artifacts contain fewer grains of this mineral group, and data are too limited to make further statements.

\section{Comparison with Jadeitite Sources Worldwide, particularly Guatemala}

The characteristics of Mesoamerican jade artifacts and comparisons with jadeitite and related rocks from Guatemala were evaluated by Harlow (1993) and Bishop et al. (1993); these references serve as a starting point for discussion of comparisons of Antigua jades and worldwide sources. Casting broadly for sources some decades ago, "diffusionist" archaeologists (those who thought advanced culture and materials were transported wholesale from Asia to Middle and South America) argued that New World jade may have been sourced from the fabulous deposits of northern Myanmar (Burma). The mineral assemblages refute this contention even if the logistical, temporal and cultural issues had not: Myanmar jadeitite conspicuously contains zoned sodic to sodic-calcic amphibole (eckermannite, nyböite, glaucophane, etc. - see Shi et al., 2003, Harlow \& Olds, 1987) and no white mica, whereas Guatemalan jadeitite, Mesoamerican jade and, as seen here, Antigua jade typically contain conspicuous white-tan mica. White mica is also absent from the jadeitite of Japan, Kazakhstan 
and Russia (see Harlow \& Sorensen, 2005); so even if it were likely that Antigua jades could be sourced from Eurasia, mineralogy serves as a critical criterion (however, the geological explanation for these fundamental differences has yet to be given).

How well does the Antigua jade match with known Guatemalan jadeitite? Are there clear matches or are unidentified or unsampled sources in Guatemala or possibly elsewhere required? These questions have become more complicated (and interesting), because there are two distinct belts of jadeitite in Guatemala: one north of the Motagua fault zone (MFZ, generally followed by the Motagua River) with consistent ${ }^{39} \mathrm{Ar}-{ }^{40} \mathrm{Ar}$ dates from mica and amphibole of 65$77 \mathrm{Ma}$, and the other to the south dating at 120-130 Ma (Harlow et al., 2003, 2004). This fact was not known when the chapters by Harlow (1993) and Bishop et al. (1993) or the description of Guatemalan jadeitite by Harlow (1994) were written. A brief description of the differences, thus, is necessary.

Jadeitite from north of the MFZ has been found along an E-W extending belt for over $100 \mathrm{~km}$, from roughly $25 \mathrm{~km}$ due north of Guatemala City (near Rincón Grande) to Río Hondo. The material is distinctively characterized by: (1) up to four micas: phengite, paragonite, preiswerkite $\left[\mathrm{Na}(\mathrm{Mg}, \mathrm{Fe})_{2} \mathrm{Al}_{(}\left(\mathrm{Al}_{2} \mathrm{Si}_{2}\right) \mathrm{O}_{10}(\mathrm{OH})_{2}\right]$ and phlogopite; (2) considerable grain boundary alteration to albite + analcime (or nepheline) + taramitic amphibole; (3) jadeite grains with numerous inclusions of albite and analcime; and, (4) the absence of quartz or lawsonite (see Table 2C; for the purposes of comparison with the relatively dark-green Antigua jade, the selection features dark-green samples, which are relatively rare in the sampling of known occurrences to the north). Metabasalt associated in these occurrences of jadeitite, which gives some indication of facies ( $P-T$ conditions), is primarily garnet-clinozoisite amphibolite and taramite omphacite rock showing rare evidence of being heavily retrograded low-T eclogite (Tsujimori et al., 2004). Compositional plots of phengite and jadeite and omphacite from the 
northern belt of jadeitite are shown in Figures 5 and 6A, respectively. A wide jadeite-omphacite gap is typical for such jadeitite, suggesting growth at $\mathrm{T}<400{ }^{\circ} \mathrm{C}$ and a modest iron enrichment trajectory from $\mathrm{Jd}_{100}$ toward between about $\mathrm{Di}_{75} \mathrm{Hd}_{10} \mathrm{Ae}_{15}$ and $\mathrm{Di}_{62} \mathrm{Hd}_{8} \mathrm{Ae}_{30}$. Phengite has $\mathrm{Mg}+\mathrm{Fe}^{2+}+\mathrm{Mn}$ based on 22 atoms of oxygen from 0.5 to 1.1 apfu and Si of 6.4 to 7.1 apfu, as shown in Figure 5.

Jadeitite from south of the MFZ has a smaller known aerial distribution, between the aldeas (villages) of Carrizal Grande and La Ensenada, roughly $15 \mathrm{~km}$ in lateral extent. These rocks are more diverse in mineral assemblages and association, but are typically characterized by: (1) only phengite and phlogopite (no paragonite or preiswerkite); (2) relatively little alteration, but where present, quartz veining is as common as albite + analcime; (3) jadeite grains with small core-cluster inclusions of omphacite and quartz; (4) more abundant titanite, typically with a rutile core, and zircon; and, (5) lawsonite and glaucophane in some cases. The metabasalt found with the jadeitite range from lawsonite eclogite with variable blueschist overprinting to omphacite-glaucophane blueschist and lawsonite-glaucophane blueschist (Sisson et al., 2003, Harlow et al., 2004, Tsujimori et al., 2006). Compositional plots of phengite and jadeite and omphacite from the southern occurrences of jadeitite are shown in Figures 5 and 6B. A wide jadeite-omphacite gap is also typical in these samples of jadeitite, suggesting growth at $\mathrm{T}$ as low as $300^{\circ} \mathrm{C}$, and a trajectory of jadeite compositions from near $\mathrm{Jd}_{100}$ toward between $(\mathrm{Di}+\mathrm{Hd})_{90} \mathrm{Ae}_{10}$ and $(\mathrm{Di}+\mathrm{Hd})_{50} \mathrm{Ae}_{50}$, Di dominating over $\mathrm{Hd}$ in lighter-colored jadeitite and in darker Di:Hd $\leq \sim 3$. Intergrown omphacite ranges from $\mathrm{Jd}_{48-54} \mathrm{Di}_{29-43} \mathrm{Hd}_{4-18} \mathrm{Ae}_{1-3}$ among paler jadeitite to $\mathrm{Jd}_{36-55} \mathrm{Di}_{20-30} \mathrm{Hd}_{3-13} \mathrm{Ae}_{16-25}$ for darker samples; aegirine content is apparently the important coloring agent. Omphacite inclusions in jadeite, with an extreme case being MVE0414-6, can have an odd "bimodal" distribution of iron-rich compositions from omphacite, e.g., $\mathrm{Jd}_{55} \mathrm{Di}_{25-35} \mathrm{Hd}_{5-20} \mathrm{Ae}_{4}$, toward aegirine, e.g., $\mathrm{Ae}_{44} \mathrm{Hd}_{30} \mathrm{Jd}_{21} \mathrm{Di}_{3}$ (Fig. 6B, C); the "regular" 
omphacite compositions represent the interstitial and late-crystallizing pyroxene whereas the excursions to high-Fe content are all small inclusions (5-20 $\mu \mathrm{m}$ across) in jadeite (i.e., there may be some overlap between the inclusion and jadeite in composition). Phengite has $\mathrm{Mg}+\mathrm{Fe}^{2+}+\mathrm{Mn}$ generally ranging 1.0 and 1.2 apfu with a few outliers to 1.5 , and Si from 6.6 to 7.1 apfu with outliers to 7.3 (Fig. 5).

From the perspective of phase assemblages, Antigua jade artifacts have an affinity with Guatemalan jadeitite, particularly samples from south of the MFZ, with the shared characteristics of containing phengite, quartz and occasionally glaucophane and lawsonite (Table 2). Although similarities abound, there are several inconsistencies, too. For example, jade objects with zoisite or clinozoisite plus quartz are not matched among studied Guatemalan material. Likewise, paragonite has not been found in quartz-bearing jadeitite from south of the MFZ.

Texturally there are strong similarities as well. The "reefs" and "atolls" of omphacite in quartz in E150 (Fig. 3A) and E92 (Fig. 3B) are shared with samples of jadeitite from south of the MFZ, such as MVE02-15-10 (Fig. 6A) or MVE03-77-5-1. The mesh-textured titanite in E92 (Fig. 3B) is another feature found in "southern" jadeitite, e.g., JJE01-3-1(Fig. 7B). Artifact E92 also exhibits the small inclusions of omphacite in jadeite with odd iron-rich omphacite-toaegirine augite compositions, not unlike MVE04-14-6 or MVE02-17-5 (Fig. 7C), both from south of the MFZ. Omphacite forms late multi-stage veins in jadeitite (Fig. 7D) as is found in some artifacts (E78, Fig 3D)

A single sample of a jadeite-rich rock from an unknown locality in Baja California, Mexico has been included in this comparison as a potential jade material from Middle America. Whereas the assemblage resembles a jadeitite, the pyroxene crystallization trends from jadeite to omphacite to aegirine, and the grain size is generally too small to determine if the apparent lack of compositional gap(s) in the compositions is real (Fig. 8). This zoning trend, exclusive of 
inclusions in jadeite (which this sample does not show), has not been observed in any other jadeitite worldwide. Moreover, it is not clear whether this material comes in pieces greater than a few centimeters in size, as the first author is familiar with another rock with the identical unclear provenance that consists primarily of densely packed blue-black aegirine florets in a matrix of jadeite + albite once offered as a new "jade." This material, although an interesting possible blueschist assemblage and worthy of further study as a jadeitite variant, does not share the characteristics of Antigua jade, or Guatemalan jadeitite for that matter.

\section{Archaeological Considerations}

The presence of jadeite jade in Saladoid age sites in Antigua is highly significant from an archaeological perspective. The Saladoid settlers are generally characterized in the archaeological literature as a highly mobile, marine-oriented society, traveling regularly between the islands in the Eastern Caribbean (Watters, 1997). The exchange of goods and raw materials among these islands is well established and was likely fuelled, in part, by the discontinuous distribution of resources among them. Materials exotic to the islands altogether, semi-precious stones for the most part, are also recovered from Saladoid sites (Cody, 1991; Murphy et al., 2000) and also present challenges with respect to their source(s).

The South American origin of the Saladoid people led to the presumption that the source areas of the exotic gem materials also lie on this continent (Rodriguez, 1991; Watters, 1997). Suggestions for South American source-areas were offered without the benefit of detailed mineralogical and petrographic knowledge of the gem materials as has been undertaken in this study. For example, three nephrite pendants and three amethyst beads from the Antigua sites were argued to come from known sources in South America on the basis of culture rather than 
analysis (Murphy et al., 2000). This research cannot address the origin of nephrite, although nephrite is fashioned in a different motif (animal or perforator pendant) than jadeitite (celt), so they must have been considered as distinctly different, whether as materials or received objects. Our demonstration of a reasonable Guatemalan origin for the Antiguan jadeite axes is significant in two ways. First, it shows the value of detailed mineralogical and petrographic studies in sourcing archaeological gem materials from the Caribbean region. Second, it strongly suggests an unanticipated Central American source for at least one of the exotic gem materials recovered from Antigua. To date, there is no documented evidence of contact between Central America and the eastern Caribbean Islands in the early part of the first Millennium A.D. Later (during the late first Millennium and early second Millennium A.D.), there are arguments for contact between inhabitants of Central America with those of the islands of the Greater Antilles (Wilson, 2005), although the nature of this contact is not known. The possibility of Guatemalan jade in Saladoid contexts on Antigua opens up exciting new avenues of research and necessitates a change in thinking in which one considers other mainland areas, such as Central America, in models of Saladoid exploration, trade and exchange.

\section{Conclusions}

The comparisons made here show that there is a strong similarity of the Antigua jade axes with jadeitite samples retrieved from the south side of the Motagua fault, although there are some differences. These differences could be attributed to the natural variation that exists in the jadeitite samples from any one locality, such that the presence or absence of in a minor phase among a few samples does not otherwise invalidate the "fingerprint" a local source. Alternatively, as there are strong mutually exclusive similarities among jadeitite either north of the fault or south of it; there may be as yet undiscovered jadeitite sources south of the MFZ from 
which the Antigua jade implements may have originated. After all, the jadeitite sources south of the MFZ were only brought to scientific attention in 2000 . However, the margin of the Caribbean tectonic plate is marked by regions of serpentinite mélange with eclogite and blueschist that are the hallmarks, although not the guarantors, of jadeitite localities. Jadeitite, after all, is much rarer in occurrence. Sources on Cuba, Hispaniola, or Jamaica thus might be found, and cannot be ruled out as possible sources for the Antigua jade.

\section{Acknowledgements}

The authors are grateful for the careful reviews of David R. Watters and Roberto Giustetto, as well as the rapid and careful attention by editor Robert F. Martin. The first author thanks Jamie Newman for considerable assistance in the preparation of samples for analysis and is grateful for support of jadeitite research by the Frohlich Charitable Trust, the Astor Expedition Fund in the Department of Earth and Planetary Sciences, AMNH, and NSF through grant EAR0309320. Dr. Mikhail Ostroumov, Universidad Michoacana de San Nicolás de Hidalgo, Mexico, kindly supplied a jadeite-rich rock from Baja California, and Grenville Draper, International University (via Sorena Sorensen, Smithsonian Institution) provided a slice of a jadeite-albitequartz rock from the Dominican Republic. The authors thank our coauthor Al Levinson for keeping us on track while he was fighting cancer; we miss his friendly persuasion. 


\section{References}

Bishop, R.L., Sayre, E.V. and Mishara, J. (1993): Compositional and structural characterization of Maya and Costa Rican jadeitites. 30-60. In Precolumbian Jade: New geological and cultural interpretations (F.W. Lange, ed.). University of Utah Press, Salt Lake City, Utah (30-60).

Carpenter, M.A. (1980): Mechanisms of exsolution in sodic pyroxenes. Contrib. Mineral. Petrol. 71, 289-300.

Castro, K. \& Castro, D. (1979): Jade in Central America. Gems and Minerals 500, 11-12, 3236.

Cody, A. (1991): Distribution of exotic stone artifacts through the Lesser Antilles: Their implications for prehistoric interaction and exchange. In Proceedings of the Fourteenth Congress of the International Association for Caribbean Archaeology (A. Cummins and P. King, eds.). Barbados, 204-226.

Coleman, R.G. (1961): Jadeite deposits of the Clear Creek area, New Idria district, San Benito County, California. J. Petrol. 2, 209-247.

Draper, G. \& Nagle, F. (1991): Geology, structure, and tectonic development of the Rio San Juan complex, northern Dominican Republic. In Geologic and Tectonic Development of the North America-Caribbean Plate Boundary in Hispaniola (P. Mann, G. Draper \& J. F. Lewis, eds.). Geol. Soc. Am. , Spec. Paper 262, 77-95.

Easby, E.K. (1991): Jade in South America and the Caribbean. In Jade (R. Keverne, ed.). Van Nostrand Reinhold, New York, 338-341.

Finger, L.W. (1972) The uncertainty in the calculated ferric iron content of a microprobe analysis. Carnegie Inst. Wash., Yearbook 71, 600-603.

Foshag, W.F. (1957): Mineralogical studies on Guatemalan jade. Smithsonian Miscellaneous 
Collections 135, No. 5, 60 pp.

\& Leslie, R. (1955): Jadeite from Manzanal, Guatemala: Am. Antiquity, 21, 81-83.

Francis, A.H., Avé Lallemant, H.G., Sisson V.B., Hemming, S.R., Roden,-Tice, M., Breuckner, H.K., Harlow, G.E. \& Chiquin, M. (2005): Two jadeitite belts in the Motagua Valley Fault Zone, Guatemala: Two subduction events or one subduction event with retrogression? Geol. Soc. Am. Abstr. Program, Annual Meeting, 37(7), 67.

Harlow, G.E. (1993): Middle American Jade: Geologic and Petrologic Perspectives on Its Variability and Source. In Precolumbian Jade: New geological and cultural interpretations (F.W. Lange, ed.). University of Utah Press, Salt Lake City, Utah (9-29). (1994): Jadeitites, albitites and related rocks from the Motagua Fault Zone, Guatemala.

J. Metamorph. Geol. 12, 49-68.

, Hemming, S.R., Avé Lallemant, H.G., Sisson, V.B. \& Sorensen, S.S. (2004): Two highpressure-low-temperature serpentine-matrix mélange belts, Motagua fault zone, Guatemala: A record of Aptian and Maastrichtian collisions. Geology 32, 17-20. \& Olds, E.P. (1987): Observations on terrestrial ureyite and ureyitic pyroxene. Am. Mineral. 72, 126-136.

, Sisson, V.B., Avé Lallemant, H.G., Sorensen, S.S. \& R. Seitz (2003): High-pressure, metasomatic rocks along the Motagua Fault Zone, Guatemala. Ofioliti 28, 115-120. \& Sorensen, S.S. (2005): Jade (nephrite and jadeitite) and serpentinite: Metasomatic connections. Int. Geol. Rev. 47, 113-146.

Monardes, N. (1580) Primera y segunda y tecera parte de la historia medicinal de las cosas que se traen de las Indias Occidentales que sirven en medicina. En casa de Fernando Diaz, Sevilla, 17r-19r.

Murphy, A.R. (1999): The prehistory of Antigua, Ceramic Age: Subsistence, settlement, 
culture and adaptation within an insular environment. Ph.D. thesis, Dept. of Archaeology, Univ. of Calgary, Calgary, Alberta, Canada. , Hozjan, D.J., de Mille, C.N. \& Levinson, A.A. (2000) Pre-Columbian gems and ornamental materials from Antigua, West Indies. Gems \& Gemol. 36, 234-245.

Okay, A.I. (1997): Jadeite—K-feldspar rocks and jadeitites from northwest Turkey. Mineral. Mag. 61, 835-843.

Pashin, A. (1995) The great California jade loop. Rock and Gem 25, No.12, 44-45, 96.

Pouchou, J.L. \& Pichoir, F. (1991): Quantitative Analysis of Homogenous or Stratified Microvolumes Applying the Model "PAP”. In Electron Probe Quantitation (K.F.K. Heinrich \& D.E. Newbury, eds.). Plenum Press, New York, 31-75.

Rodriguez, M. (1991): Early trade networks in the Caribbean. In Proceedings of the Fourteenth Congress of the International Association for Caribbean Archaeology (A. Cummins and P. King, Eds.). Barbados, 306-314.

Seitz, R., Harlow, G.E., Sisson, V.B. \& Taube, K.A. (2001): Formative jades and expanded jade sources in Guatemala: Antiquity 87, 687-88.

Shi, G.H., Cui, W.Y, Tropper, P., Wang, CQ., Shu, G-M. \& Yu, H. (2003): The petrology of a complex sodic and sodic-calcic amphibole association and its implications for the metasomatic processes in the jadeitite area in northwestern Myanmar, formerly Burma. Contrib. Mineral. Petrol. 145, 355-376.

Sisson, V.B., Harlow, G.E., Sorensen, S.S., Brueckner, H.K., Sahm, E., Hemming, S. \& Avé Lallemant, H.G. (2003): Lawsonite eclogite and other high-pressure assemblages in the southern Motagua Fault zone, Guatemala: Implications for Chortís Collision and Subduction Zones. Geol. Soc. Am. Abstr. Program, Annual Meeting, 35(7), A-639.

Sorensen, S.S. \& Harlow, G.E. (1999): The geochemical evolution of jadeitite-depositing 
fluids. Geol. Soc. Am. Abstr. Program, Annual Meeting, 31(7), A-101.

Taube, K.A., Sisson, V.B., Seitz, R. \& Harlow, G.E. (2004): The sourcing of Mesoamerican jade: Expanded geological reconnaissance in the Motagua Region, Guatemala. In Olmec Art and Dumbarton Oaks (K. A. Taube). Pre-Columbian Art at Dumbarton Oaks, 2, Dumbarton Oaks, Washington, D.C. 203-228.

Tsujimori, T., Liou, J.G. \& Coleman, R.G. (2004): Comparison of two contrasting eclogites from the Motagua fault zone, Guatemala: Southern lawsonite eclogite versus northern zoisite eclogite. Geol. Soc. Am. Abstr. Program, Annual Meeting, 36(5), 136.

, Sisson, V.B., Liou, J.G., Harlow, G.E. \& Sorensen, S.S. (2006) Petrologic characterization of Guatemalan lawsonite-eclogite: Direct information on eclogitization of subducted oceanic crust in a cold subduction zone. In Ultrahigh-Pressure Metamorphism: Deep Continental Subduction (B.H. Hacker, W.C. McClelland \& J.G. Liou, eds.). Geol. Soc. Amer. Special Paper, 403, 147-168.

Watters, D. R. (1997): Maritime trade in the prehistoric Eastern Caribbean. In The Indigenous People of the Caribbean (S. M. Wilson, ed.). University of Florida Press, Gainesville, Fl (88-99).

Wilson, S. M. (2005): Stone pavements, roads and enclosures in Central America and the Caribbean. Paper presented at the 21st International Congress for Caribbean Archaeology, University of the West Indies, St. Augustine, Trinidad and Tobago, July 24-30, 2005. 


\section{Figure Captions}

Figure 1. Map of the Caribbean region showing the isle of Antigua in relation to Guatemala, where the jade source area is shaded, and a detailed inset of the area.

Figure 2. Photographs of Antigua jades examined in this study (except E91): A) E78; B) E92; C) E93; D) E94; E) E150; F) E152; G) E153; H) MR76, and I) W.

Figure 3. Back-scattered electron (BSE) images of Antigua jades: A) E150 - jadeite grains with inclusions of quartz and some surrounded by "reef-like" omphacite in a matrix of quartz. B) E92 - massive jadeite with cores of grains containing inclusions of omphacite and quartz; a mesh-textured titanite grain and an irregular area of quartz with an "atoll" ring of omphacite are also shown. C) E152 shows a tightly knit intergrowth of jadeite grains with occasional quartz inclusions associated with minor omphacite zones; other omphacite regions do not appear to have associated quartz. D) E78 illustrates a roughly equal distribution of jadeite and irregularly zoned omphacite (variation in gray level), abundant titanite and a few cubes of pyrite, cut by a vein of omphacitite.

Figure 4. Ternary plots of pyroxene compositions (individual microprobe analyses) from Antigua jades. Corners are molecular proportions of pyroxene components of diopside + hedenbergite $(\mathrm{Di}+\mathrm{Hd})$, aegirine (Ae) and jadeite $(\mathrm{Jd})$. Nominal jadeite and omphacite are shown in light and dark green, respectively. 
Figure 5. Plot of Si vs. $\mathrm{Mg}+\mathrm{Fe}^{2+}+\mathrm{Mn}$ atoms per formula unit for compositions of phengitic muscovite (individual microprobe analyses) in Antigua jades compared with those from samples of jadeitite and albitite from the jade belts in Guatemala.

Figure 6. Ternary plots representative of pyroxene compositions (individual microprobe analyses) from samples of jadeitite from Guatemala and Antigua jades. A) $\mathrm{Di}+\mathrm{Hd}-\mathrm{Ae}-\mathrm{Jd}$ plot for selected jadeitite from north of the Motagua fault zone (MFZ). B) the same for jadeitite south of the MFZ. C) Di - Hd+Ae - Jd ternary plot for artifact E92 and samples MVE04-14-6 and MVE02-17-5 of Guatemalan jadeitite; symbol shapes denote samples as shown, light color for jadeite and dark color for omphacite.

Figure 7. Back-scattered electron (BSE) images of samples of Guatemalan jadeitite: A) MVE02-15-10, Quartz Jadeitite, Quebrada Seca, Carrizal Grande, Jalapa Dept.: In addition to composite titanite-apatite grains, the lower portion of the image shows omphacite + diopside grains forming a reef-like border in the quartz adjacent to a jadeite grain. B) JJE01-3-1, Jadeitite, Quebrada El Escorpión, Carrizal Grande, Jalapa Dept.: A mesh-textured titanite typical of titanite associated with late omphacite and veins in these rocks. C) MVE04-14-6, Jadeitite, Quebrada Seca, Carrizal Grande, Jalapa Dept.: Small inclusions of omphacite, sometimes showing distinct zones with low and high iron, abound in this sample - many also have adjacent quartz or a fluid inclusion. D) KT02-3, Jadeitite, Quebrada Seca, Carrizal Grande, Jalapa Dept.: Late omphacite in veins shows at least two stages of growth as seen by differences in lighter gray levels.

Figure 8. A ternary $\mathrm{Di}+\mathrm{Hd}-\mathrm{Ae}-\mathrm{Jd}$ plot of pyroxene compositions from a jadeite-bearing rock from Baja California, Mexico. 
Table 1. Antigua jade samples

Artifact Site

\section{Description}

MR76 Mill Reef A dark green (where shiny) to emerald-green celt $(6.4 \mathrm{~cm}$ long) with white indentations where apparent weathering of mica has occurred

E78 Elliot's A polished button-sized slice $(1.5 \mathrm{~cm}$ diameter) from the tang end of a celt with a slightly foliated layering of sheath-like dark green and lighter green grains, decorated with blotchy intergrowths of pyrite.

E91 Elliot's Sample was examined at a preliminary stage and can no longer be located.

E92 Elliot's A fragment $(3.4 \times 2.3 \mathrm{~cm})$ of a celt with dark blue-green body color and whitish blotchy areas on the original surface of the celt ; a new polish on the fractured surface shows mostly a uniform dark green color with very small lighter blotches (the brownish spots are surface stains in indentations).

E93 Elliot's Finely mottled white-green slices $(4.5 \times 2.3 \mathrm{~cm})$ of a celt, coarsely mottled with whitish (jadeitic) and intense green (omphacitic) clots.

E94 Elliot's Broken tang-end of a celt consisting of mottled granular white-togreen areas. Millimeter-sized grains are internally turbid (corecluster inclusions) and one side has coarse (mm-sized crystals) vein of intergrown zoisite and paragonite.

E150 Elliot's Blotchy white to dark-green fragment $(3.1 \times 2.5 \mathrm{~cm})$ with fine dusting of "black" titanite associated with the green areas, not noticeably foliated.

E152 Elliot's Medium green, slightly variegated, jadeitite $(3.2 \times 3 \mathrm{~cm})$ fragment with fan-spherulitic grains and a dark green vein cutting through the middle.

E153 Elliot's Pale to medium green jadeitite fragment, apparently from flat surface of a celt $(3 \times 2.1 \mathrm{~cm})$, with pasty white patches and pistachio-green anastomosing veinlets, included larger grains and some glassy transparent grains (albite).

W Elliot's Fragment of the flattest surface of a jade celt (?) $(4.5 \times 3.7 \mathrm{~cm})$; whitish green body color with short ribbonlets of dark green omphacite following a subtle foliation; many reflecting grains of white mica are visible. 
Table 2. Mineralogy of samples used in this study

A: Jadeite Jades (Jadeitite) analyzed with SEM/BSE and microprobe.

\begin{tabular}{|c|c|c|c|c|c|c|c|c|c|c|c|c|c|c|c|}
\hline & jd & omp & $a b$ & wm & qtz & anl & amp & Zo & law & rut & $\operatorname{ttn}$ & $\mathrm{zr}$ & other & Description & Locality \\
\hline$\overline{E 78}$ & $x$ & $x$ & & ph & & & & al & & & $x$ & & py & Dark green & Elliot's \\
\hline E92 & $x$ & $x$ & $x$ & pg,ph? & $x$ & & & $x$ & & $x$ & $x$ & $x$ & & Leak green jade & Elliot's \\
\hline E93 & $x$ & $x$ & $x$ & & $x$ & $x$ & & $x$ & $x$ & $x$ & $x$ & $x$ & apt,pmp & Variegated green & Elliot's \\
\hline E150 & $x$ & $x$ & $x$ & ph & $x$ & & gln & CZO & & & $x$ & $x$ & apt & Variegated green & Elliot's \\
\hline E152 & $x$ & $x$ & $x$ & ph,phl & $x$ & & & czo,al & & & $x$ & $x$ & apt, bar & Variegated green & Elliot's \\
\hline E153 & $x$ & x,aug & $x$ & pg,phl & $x$ & & & $\mathrm{ZO}, \mathrm{CZC}$ & & & $x$ & $x$ & & & Pale green Elliot's \\
\hline
\end{tabular}

B: Jadeite Jades examined by X-ray diffraction $(x)$ and/or optical petrography (o).

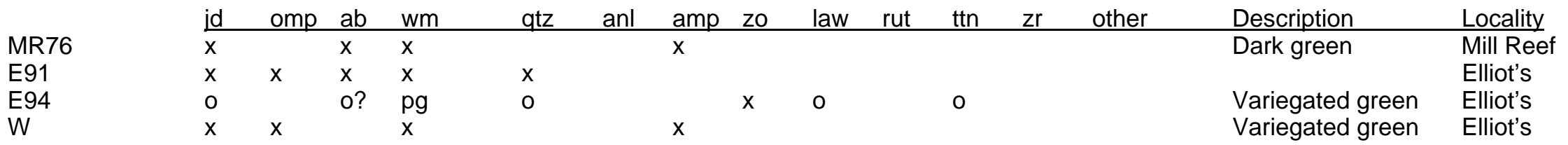

C: Jadeitite and omphacitite from Guatemala.

\begin{tabular}{|c|c|c|c|c|c|c|c|c|c|c|c|c|c|c|c|}
\hline North of MFZ & jd & omp & $a b$ & $\mathrm{wm}$ & qtz & anl & amp & zo & law & rut & $\operatorname{ttn}$ & $\mathrm{zr}$ & other & Description & Locality \\
\hline AMNH 45049 & $x$ & $x$ & $x$ & $\mathrm{pg}$ & & & $x$ & ZO & & & $x$ & & prs & Light green & Manzanal \\
\hline $\mathrm{R}-10$ & $x$ & $x$ & & & & & act & & & & & & chl & Foliage & Río La Palmilla \\
\hline $\mathrm{R}-13$ & $x$ & $x$ & $x$ & $\mathrm{pg}$ & & & & & & & & & & Foliage & Río La Palmilla \\
\hline MVJ84-9C-1 & $x$ & $x$ & $x$ & $\mathrm{pg}$ & & $x$ & $x$ & $x$ & & $x$ & $x$ & $x$ & bnl,ne,prs & Lt. \& dark green & Quebrada Escorpión \\
\hline RSJO0-6 & $x$ & $x$ & & phl,pg & & $x$ & mtar & CZO & & & $x$ & & prs & Med green & El Ciprés \\
\hline RSJO0-7 & $x$ & $x$ & $x$ & prs & & $?$ & & CZO & & & $x$ & $x$ & & Med green & El Ciprés \\
\hline MVE02-2-5 & $x$ & $x$ & $x$ & $\mathrm{pg}$ & & $x$ & mtar & & & & $x$ & $x$ & prs,bnl & Green white & Panaluya-Río Ho \\
\hline MVJ84-44-2 & & $x$ & $x$ & & & & $\mathrm{~m} / \mathrm{tar}$ & & & $x$ & & & apt,cpy,chl & Black Jade & Río La Palmilla \\
\hline NHMLAC 20368 & $x$ & $x$ & $x$ & $\mathrm{pg} / \mathrm{phl}$ & & & & $?$ & & $x$ & $x$ & $x$ & chl,hyl,gph & Dark green & Río La Palmilla \\
\hline
\end{tabular}




\begin{tabular}{|c|c|c|c|c|c|c|c|c|c|c|c|c|c|c|c|}
\hline South of MFZ & jd & omp & $a b$ & wm & qtz & anl & amp & $z O$ & law & rut & $\operatorname{ttn}$ & $\mathrm{zr}$ & other & Description & Locality \\
\hline JJE01-3-1 & $x$ & $x$ & $x$ & ph & $x$ & $x$ & & al & & $x$ & $x$ & $x$ & apt & Dark-green & S. Q. El Silencio \\
\hline JJE01-3-4 & $x$ & $x$ & & ph & $?$ & & gln & & & $x$ & $x$ & $x$ & & Med green & S. Q. El Silencio \\
\hline JJE01-6-1 & $x$ & $x$ & & ph & & & & $?$ & $x$ & $x$ & $x$ & $x$ & apt & Dark-green & Río La Puerta \\
\hline MVE02-15-10 & $x$ & $\mathrm{x}, \mathrm{di}$ & $x$ & ph & $x$ & & act & & & $x$ & $x$ & $x$ & apt & Dark gray-green & Q. Seca \\
\hline MVE04-14-6 & $x$ & $x$ & $x$ & ph & $x$ & $x$ & & & & $x$ & $x$ & $x$ & cym & Med. Green & Q. Seca \\
\hline JJE01-X-3 & $x$ & $x$ & $x$ & Ba-ph & $x$ & $x$ & gln & & $x$ & $x$ & $x$ & $x$ & apt & Med green & Río El Tambor \\
\hline MVE02-17-5 & $x$ & $x$ & & & $x$ & & & & & $x$ & $x$ & $x$ & cym,ve & t Med. Green & La Ceiba \\
\hline MVE03-77-1 & $x$ & $x$ & $x$ & ph & $x$ & & & al & & & $x$ & $x$ & chl & Dark green & La Ceiba \\
\hline
\end{tabular}

\section{Single Jadeite-omphacite rock from Baja California, Mexico.}

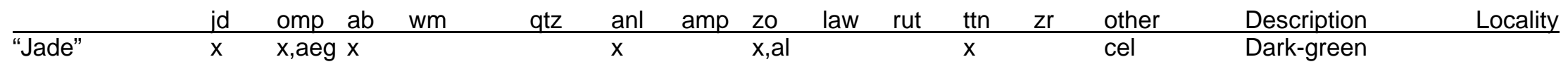

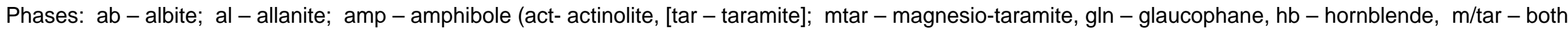

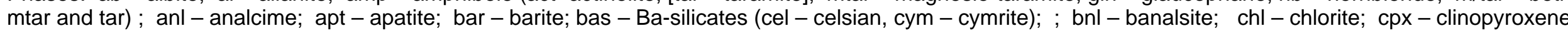

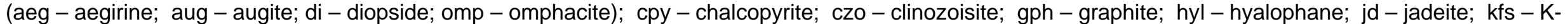

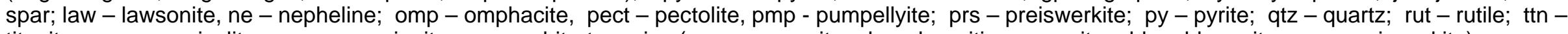

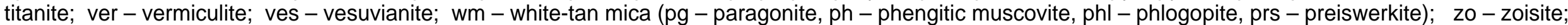
$\mathrm{zr}$ - zircon. 
Table 3. Representative compositions of minerals in Antigua jades

\begin{tabular}{|c|c|c|c|c|c|c|c|c|c|c|}
\hline & $\begin{array}{r}\mathrm{Jd} \\
\mathrm{E} 78 \\
\end{array}$ & $\begin{array}{r}\text { Omp } \\
\text { E78 }\end{array}$ & $\begin{array}{l}\mathrm{Jd} A \\
\mathrm{E} 92\end{array}$ & $\begin{array}{r}\text { g-Aug } \\
\text { E92 }\end{array}$ & $\begin{array}{r}J d \\
\mathrm{E} 150 \\
\end{array}$ & $\begin{array}{l}\text { Omp } \\
\text { E150 }\end{array}$ & $\begin{array}{r}J d \\
\text { E152 }\end{array}$ & $\begin{array}{l}\text { Omp } \\
\text { E152 }\end{array}$ & $\begin{array}{r}J d \\
\mathrm{E} 153 \\
\end{array}$ & $\begin{array}{r}\text { Aug } \\
\text { E153 }\end{array}$ \\
\hline $\mathrm{SiO}_{2}$ & 58.76 & 54.84 & 56.97 & 52.84 & 58.28 & 56.10 & 58.37 & 55.40 & 58.35 & 53.56 \\
\hline $\mathrm{TiO}_{2}$ & .57 & .10 & 0.40 & 0.13 & 0.06 & 0.11 & 0.02 & 0.20 & 0.06 & 0.00 \\
\hline $\mathrm{Al}_{2} \mathrm{O}_{3}$ & 20.97 & 8.53 & 19.03 & 4.18 & 21.02 & 11.76 & 21.33 & 6.73 & 19.72 & 3.52 \\
\hline $\mathrm{Cr}_{2} \mathrm{O}_{3}$ & 0.00 & .04 & 0.00 & 0.02 & 0.01 & 0.02 & 0.00 & 0.05 & 0.02 & 0.00 \\
\hline $\mathrm{Fe}_{2} \mathrm{O}_{3}$ & .00 & 6.36 & 4.01 & 16.64 & 2.69 & 2.28 & 3.72 & 8.82 & 1.94 & 3.97 \\
\hline $\mathrm{FeO}$ & .46 & 2.52 & 0.55 & 1.98 & 0.16 & 2.82 & 0.07 & 2.31 & 0.75 & 4.81 \\
\hline $\mathrm{MnO}$ & .03 & .25 & 0.00 & 0.23 & 0.11 & 0.10 & 0.06 & 0.17 & 0.09 & 0.17 \\
\hline $\mathrm{MgO}$ & 2.95 & 7.03 & 1.70 & 5.12 & 1.54 & 6.69 & 1.11 & 7.42 & 2.57 & 11.02 \\
\hline $\mathrm{CaO}$ & 4.01 & 11.44 & 2.85 & 9.63 & 2.68 & 11.77 & 2.09 & 12.16 & 3.89 & 19.34 \\
\hline $\mathrm{BaO}$ & .04 & .00 & 0.04 & 0.00 & 0.00 & 0.01 & 0.02 & 0.00 & 0.00 & 0.00 \\
\hline $\mathrm{Na}_{2} \mathrm{O}$ & 12.20 & 7.65 & 13.20 & 8.53 & 13.64 & 8.03 & 14.01 & 7.57 & 12.81 & 3.15 \\
\hline $\mathrm{K}_{2} \mathrm{O}$ & $0.16^{*}$ & 0.08 & 0.01 & 0.03 & 0.01 & 0.00 & 0.02 & 0.02 & 0.01 & 0.02 \\
\hline Total & 100.15 & 98.84 & 98.76 & 99.32 & 100.21 & 99.70 & 100.81 & 100.85 & 100.21 & 99.55 \\
\hline Cations: $\mathrm{O}=$ & 6 & 6 & 6 & 6 & 6 & 6 & 6 & 6 & 6 & 6 \\
\hline $\mathrm{Si}$ & 1.998 & 1.998 & 1.992 & 1.980 & 1.992 & 1.997 & 1.987 & 1.996 & 2.001 & 1.981 \\
\hline${ }^{[4]} \mathrm{Al}$ & 0.002 & 0.002 & 0.008 & 0.020 & 0.008 & 0.003 & 0.013 & 0.004 & 0.000 & 0.019 \\
\hline Sum T & 2.000 & 2.000 & 2.000 & 2.000 & 2.000 & 2.000 & 2.000 & 2.000 & 2.001 & 2.000 \\
\hline $\mathrm{Ti}$ & 0.015 & 0.003 & 0.011 & 0.004 & 0.002 & 0.003 & 0.000 & 0.006 & 0.002 & 0.000 \\
\hline${ }^{[6]} \mathrm{Al}$ & 0.838 & 0.365 & 0.777 & 0.164 & 0.840 & 0.490 & 0.843 & 0.282 & 0.797 & 0.135 \\
\hline $\mathrm{Cr}$ & 0.000 & 0.001 & 0.000 & 0.001 & 0.000 & 0.001 & 0.000 & 0.002 & 0.001 & 0.000 \\
\hline $\mathrm{Fe}^{3+}$ & 0.000 & 0.174 & 0.106 & 0.469 & 0.069 & 0.061 & 0.095 & 0.239 & 0.050 & 0.110 \\
\hline $\mathrm{Fe}^{2+}$ & 0.013 & 0.077 & 0.016 & 0.062 & 0.005 & 0.084 & 0.002 & 0.070 & 0.021 & 0.149 \\
\hline $\mathrm{Mn}$ & 0.001 & 0.008 & 0.000 & 0.007 & 0.003 & 0.003 & 0.002 & 0.005 & 0.003 & 0.005 \\
\hline $\mathrm{Mg}$ & 0.150 & 0.382 & 0.089 & 0.286 & 0.079 & 0.355 & 0.056 & 0.398 & 0.132 & 0.607 \\
\hline $\mathrm{Ca}$ & 0.146 & 0.447 & 0.107 & 0.387 & 0.098 & 0.449 & 0.076 & 0.470 & 0.143 & 0.767 \\
\hline $\mathrm{Na}$ & 0.804 & 0.540 & 0.895 & 0.619 & 0.904 & 0.554 & 0.925 & 0.529 & 0.852 & 0.226 \\
\hline K & 0.007 & 0.004 & 0.000 & 0.002 & 0.001 & 0.000 & 0.001 & 0.001 & 0.001 & 0.001 \\
\hline $\mathrm{Ba}$ & 0.001 & 0.000 & 0.001 & 0.000 & 0.000 & 0.000 & 0.000 & 0.000 & 0.000 & 0.000 \\
\hline Sum & 3.973 & 4.000 & 4.000 & 4.000 & 4.000 & 4.000 & 4.000 & 4.000 & 4.000 & 4.000 \\
\hline MMF & .916 & 0.819 & 0.846 & 0.805 & 0.910 & 0.803 & 0.939 & 0.842 & 0.845 & 0.798 \\
\hline
\end{tabular}


Table 3. Representative compositions of minerals in Antigua jades (continued)

\begin{tabular}{|c|c|c|c|c|c|c|c|c|}
\hline & $\begin{array}{r}\mathrm{Ph} \\
\mathrm{E} 150 \\
\end{array}$ & $\begin{array}{r}\mathrm{Ph} \\
\mathrm{E} 152 \\
\end{array}$ & $\begin{array}{r}\mathrm{Pg} \\
\mathrm{E} 153 \\
\end{array}$ & $\begin{array}{r}\text { Gln } \\
\text { E152 } \\
\end{array}$ & $\begin{array}{r}\text { Czo } \\
\text { E152 } \\
\end{array}$ & $\begin{array}{r}\text { Zoi } \\
\text { E153 } \\
\end{array}$ & $\begin{array}{r}\text { Czo } \\
\text { E153 } \\
\end{array}$ & $\begin{array}{r}\text { Ttn } \\
\text { E152 } \\
\end{array}$ \\
\hline $\mathrm{SiO}_{2}$ & 52.26 & 50.40 & 48.39 & 57.74 & 38.00 & 39.21 & 38.32 & 30.71 \\
\hline $\mathrm{TiO}_{2}$ & 0.11 & 25 & 0.05 & 0.02 & 0.04 & 0.05 & 0.38 & 39.23 \\
\hline $\mathrm{Al}_{2} \mathrm{O}_{3}$ & 26.83 & 27.43 & 39.12 & 11.50 & 24.85 & 32.39 & 28.62 & 1.28 \\
\hline $\mathrm{Cr}_{2} \mathrm{O}_{3}$ & 0.08 & 0.00 & 0.00 & 0.00 & 0.00 & 0.03 & 0.01 & 0.00 \\
\hline $\mathrm{Fe}_{2} \mathrm{O}_{3}$ & 0.00 & 0.00 & 0.00 & 0.21 & 11.42 & 1.09 & 5.62 & \\
\hline $\mathrm{FeO}$ & 1.83 & 3.09 & 0.31 & 8.30 & - & - & - & 0.13 \\
\hline $\mathrm{Mn}_{2} \mathrm{O}_{3}$ & - & - & - & - & 0.13 & 0.03 & 0.14 & \\
\hline $\mathrm{MnO}$ & 0.00 & 0.00 & 0.00 & 0.11 & - & - & - & 0.02 \\
\hline $\mathrm{gO}$ & 4.03 & 3.67 & 0.37 & 10.28 & 0.03 & 0.00 & 0.05 & 0.00 \\
\hline $\mathrm{aO}$ & 0.00 & 0.10 & 0.15 & 0.71 & 23.40 & 24.33 & 23.76 & 28.20 \\
\hline $\mathrm{O}$ & 0.55 & 0.49 & 0.10 & 0.00 & 0.02 & 0.01 & 0.00 & 0.02 \\
\hline $\mathrm{Na}_{2} \mathrm{O}$ & 0.30 & 0.25 & 6.32 & 7.05 & 0.02 & 0.00 & 0.03 & 0.05 \\
\hline $\mathrm{K}_{2} \mathrm{O}$ & 9.46 & 10.04 & 0.99 & 0.02 & 0.01 & 0.01 & 0.02 & 0.04 \\
\hline $\mathrm{H}_{2} \mathrm{O}^{*}$ & 4.53 & 4.49 & 4.74 & 2.16 & 1.90 & 1.96 & 1.92 & - \\
\hline Total & 99.99 & 100.20 & 100.53 & 98.10 & 99.82 & 99.11 & 98.87 & 99.67 \\
\hline Cations: O & 20 & 20 & 20 & 22 & 24 & 24 & 24 & 10 \\
\hline Si & 6.913 & 6.734 & 6.126 & 7.998 & 6.006 & 6.009 & 5.991 & 2.003 \\
\hline${ }^{[4]} \mathrm{Al}$ & 1.087 & 1.266 & 1.874 & 0.002 & - & - & - & - \\
\hline SUM T & 8.000 & 8.000 & 8.000 & 8.000 & - & - & - & - \\
\hline $\mathrm{Ti}$ & 0.011 & 0.025 & 0.005 & 0.002 & 0.005 & 0.006 & 0.044 & 1.924 \\
\hline${ }^{[6]} \mathrm{Al}$ & 3.097 & 3.053 & 63 & 1.876 & 4.628 & 5.850 & 5.274 & 0.098 \\
\hline $\mathrm{Cr}$ & 0.009 & 0.000 & 0.000 & 0.000 & 0.000 & 0.004 & 0.001 & 0.000 \\
\hline $\mathrm{Fe}^{3+}$ & 0.000 & 0.000 & 0.000 & 0.021 & 1.358 & 0.125 & 0.661 & \\
\hline $\mathrm{Fe}^{2+}$ & 0.203 & 0.345 & 0.033 & 0.961 & - & - & - & 0.007 \\
\hline $\mathrm{Mn}^{3+}$ & - & - & 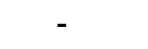 & - & 0.016 & 0.004 & 0.017 & - \\
\hline $\mathrm{Mn}^{2+}$ & 0.001 & 0.000 & 0.000 & 0.013 & - & - & - & 0.001 \\
\hline $\mathrm{Mg}$ & 0.795 & 0.731 & 0.069 & 2.123 & 0.007 & 0.001 & 0.012 & 0.000 \\
\hline $\mathrm{Ca}$ & 0.000 & 0.014 & 0.021 & 0.105 & 3.962 & 3.994 & 3.981 & 1.971 \\
\hline $\mathrm{Ba}$ & 0.029 & 0.026 & 0.005 & 0.000 & 0.001 & 0.000 & 0.000 & 0.000 \\
\hline $\mathrm{Na}$ & 0.077 & 0.066 & 1.551 & 1.894 & 0.006 & 0.000 & 0.009 & 0.006 \\
\hline K & 1.596 & 1.711 & 0.160 & 0.004 & 0.001 & 0.002 & 0.003 & $\underline{0.003}$ \\
\hline Sum & 13.816 & 13.970 & 13.806 & 15.000 & 15.992 & 15.995 & 15.994 & 6.015 \\
\hline $\mathrm{OH}^{*}$ & 4.000 & 4.000 & 4.000 & 2.000 & 2.000 & 2.000 & 2.000 & 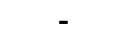 \\
\hline
\end{tabular}

* Formula is calculated with $20 \mathrm{O}+4(\mathrm{OH})$ for mica, $22 \mathrm{O}+2(\mathrm{OH})$ for amphibole and $24 \mathrm{O}+2(\mathrm{OH})$ for zoisite/epidote; $\mathrm{OH}$ is calculated to fill univalent anion site and $\mathrm{H}_{2} \mathrm{O}$ is back calculated from the conversion of ions to $w t \% s$. 
Figure 1

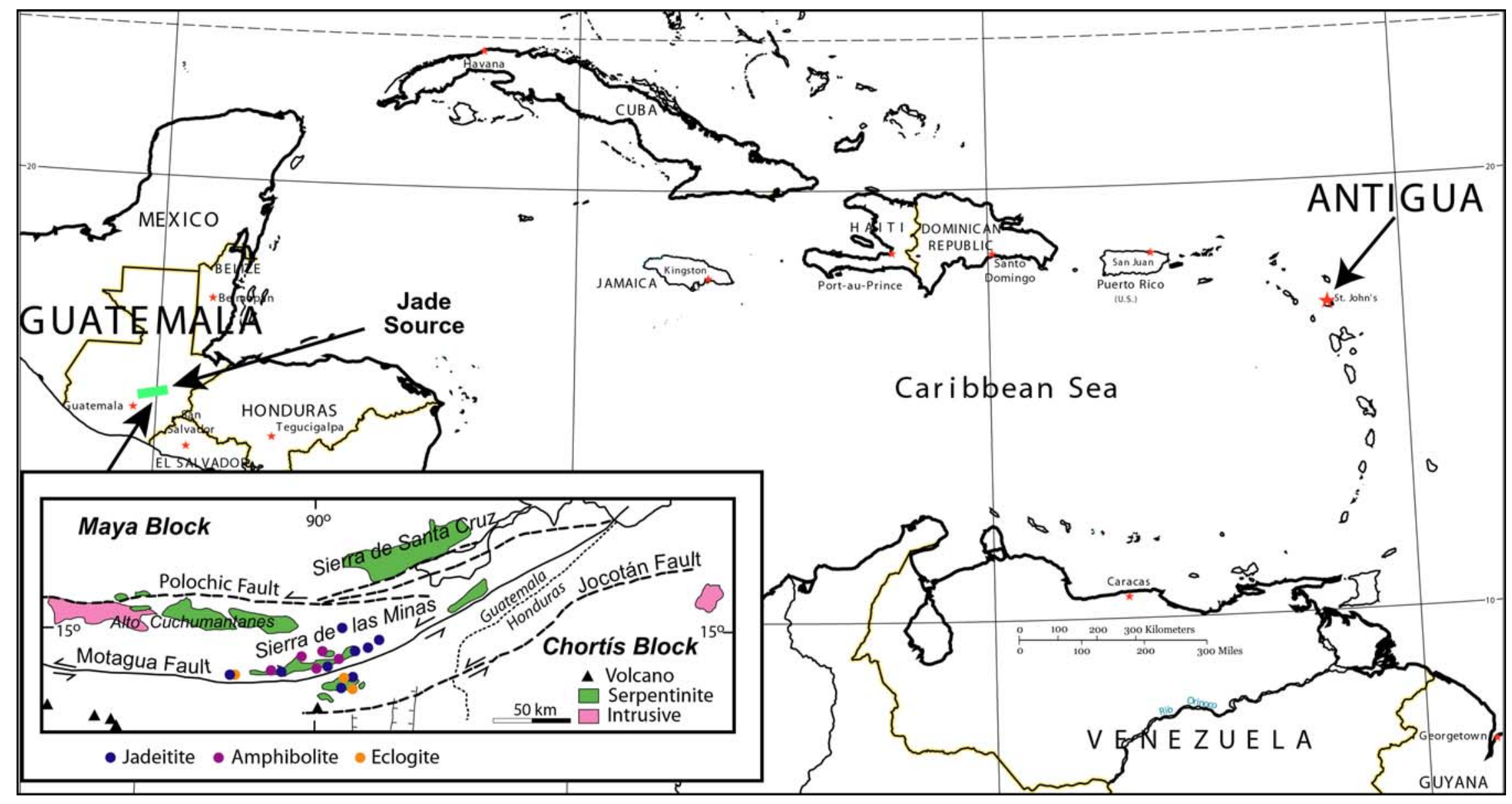


Figure 2

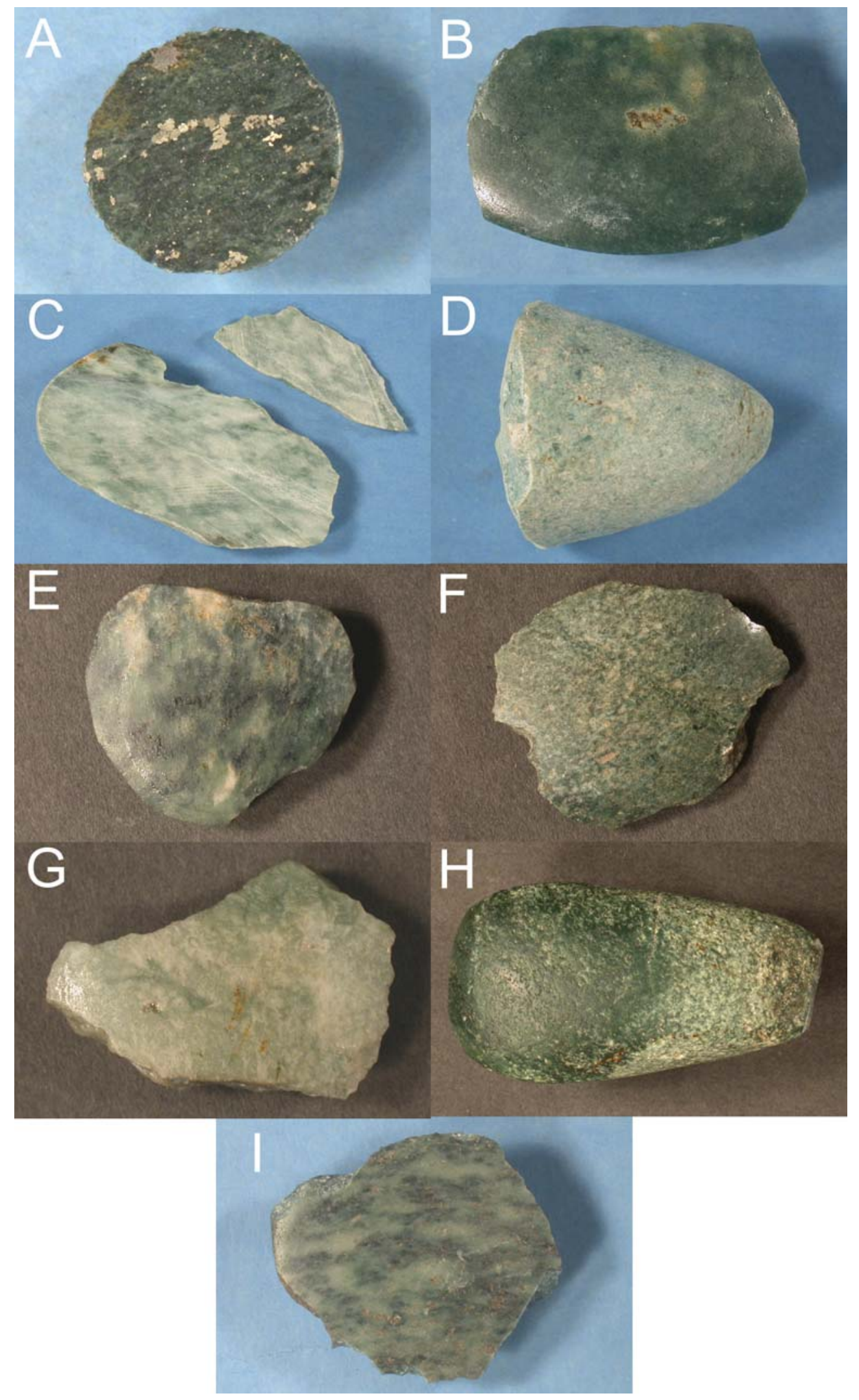


Figure 3
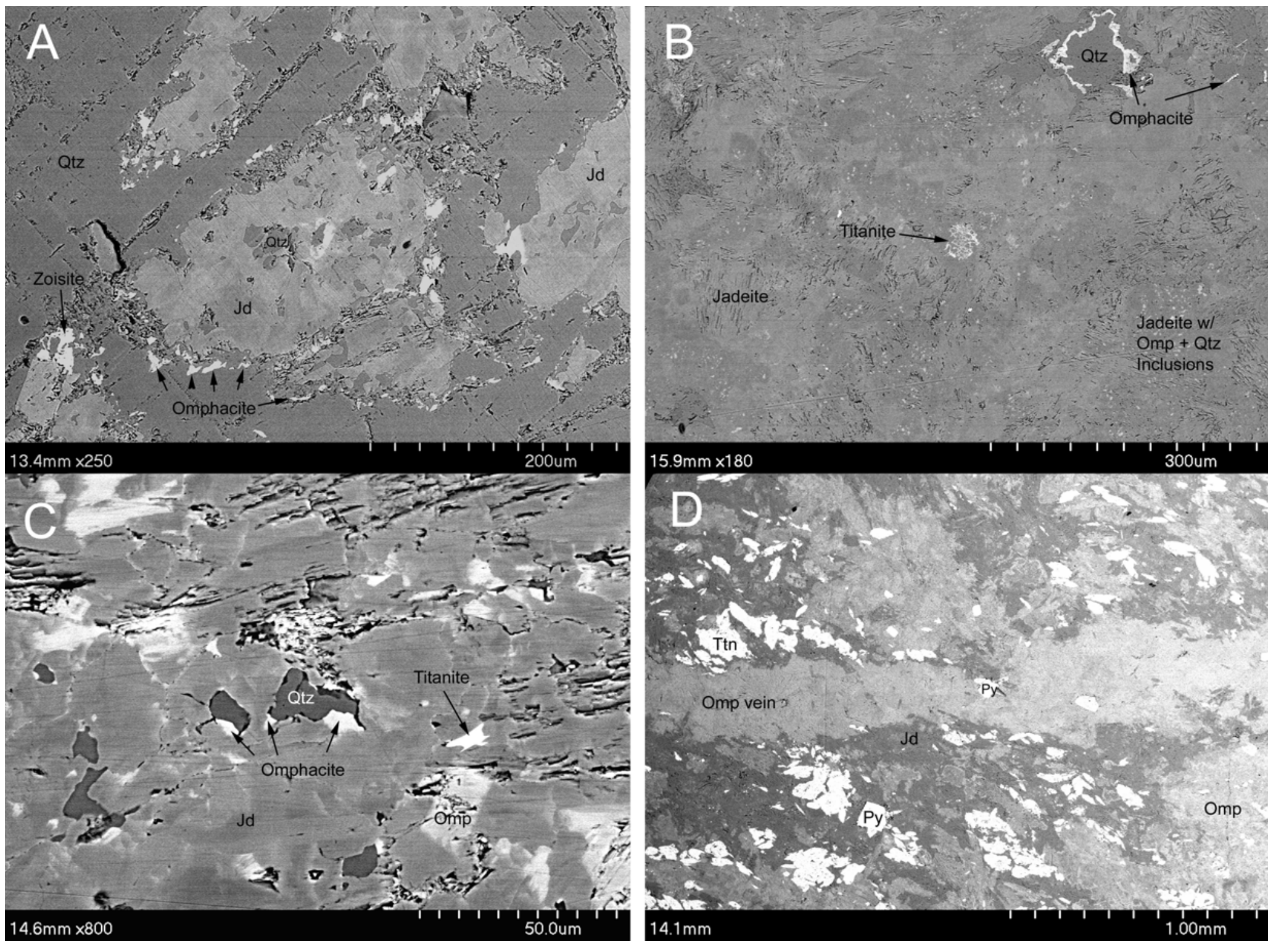

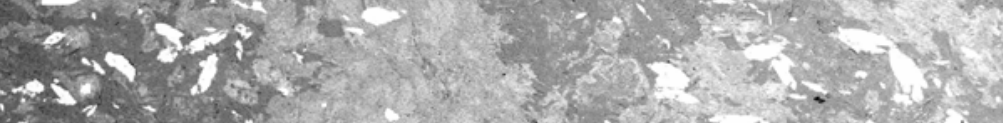

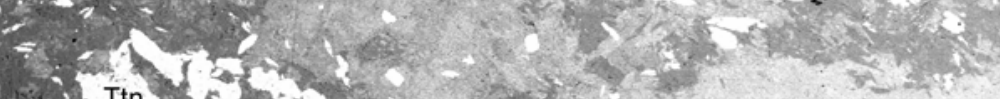

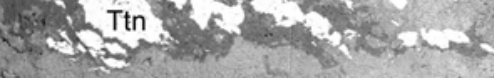

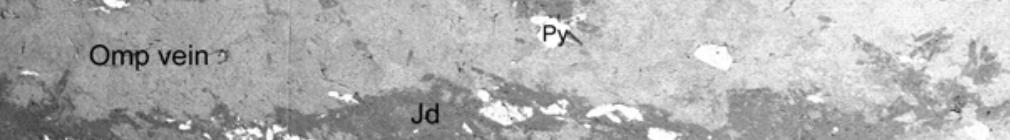

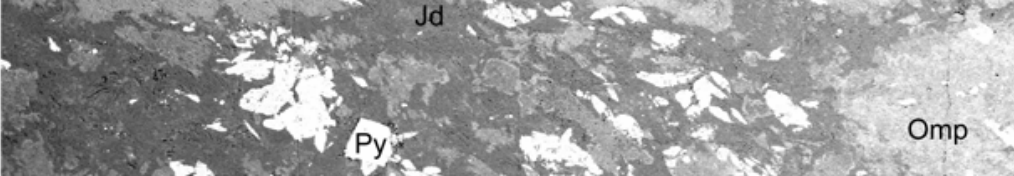

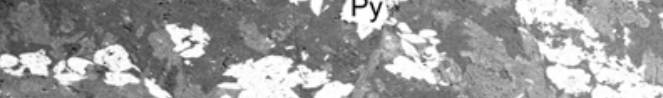

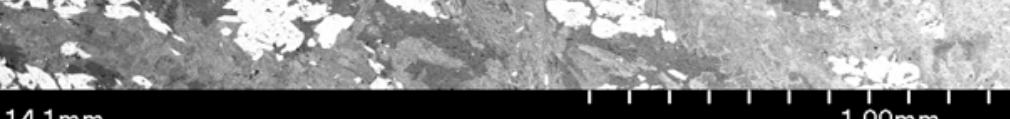


Figure 4
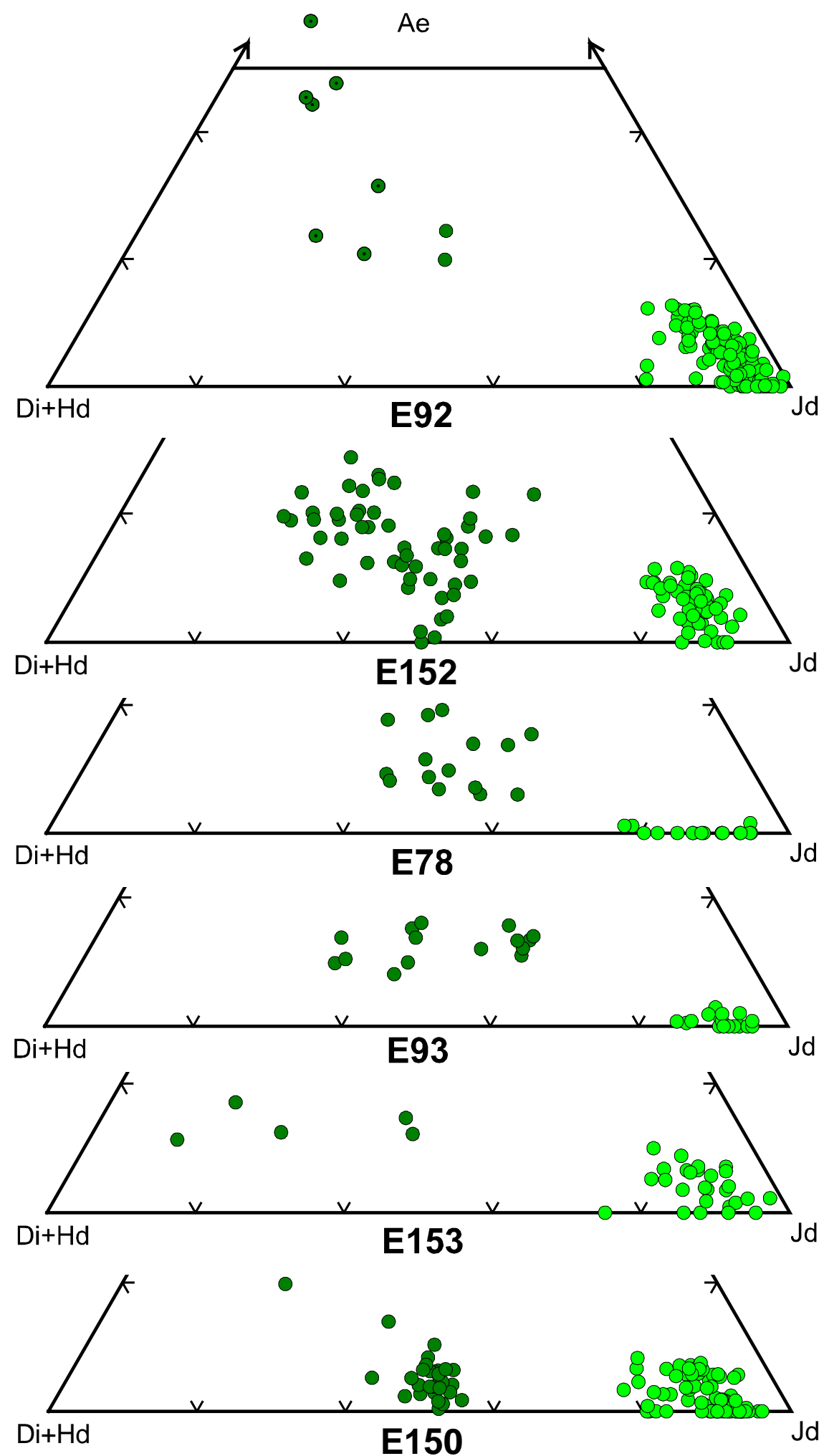
Figure 5

\section{Phengite in Jadeitite \& Albitite}

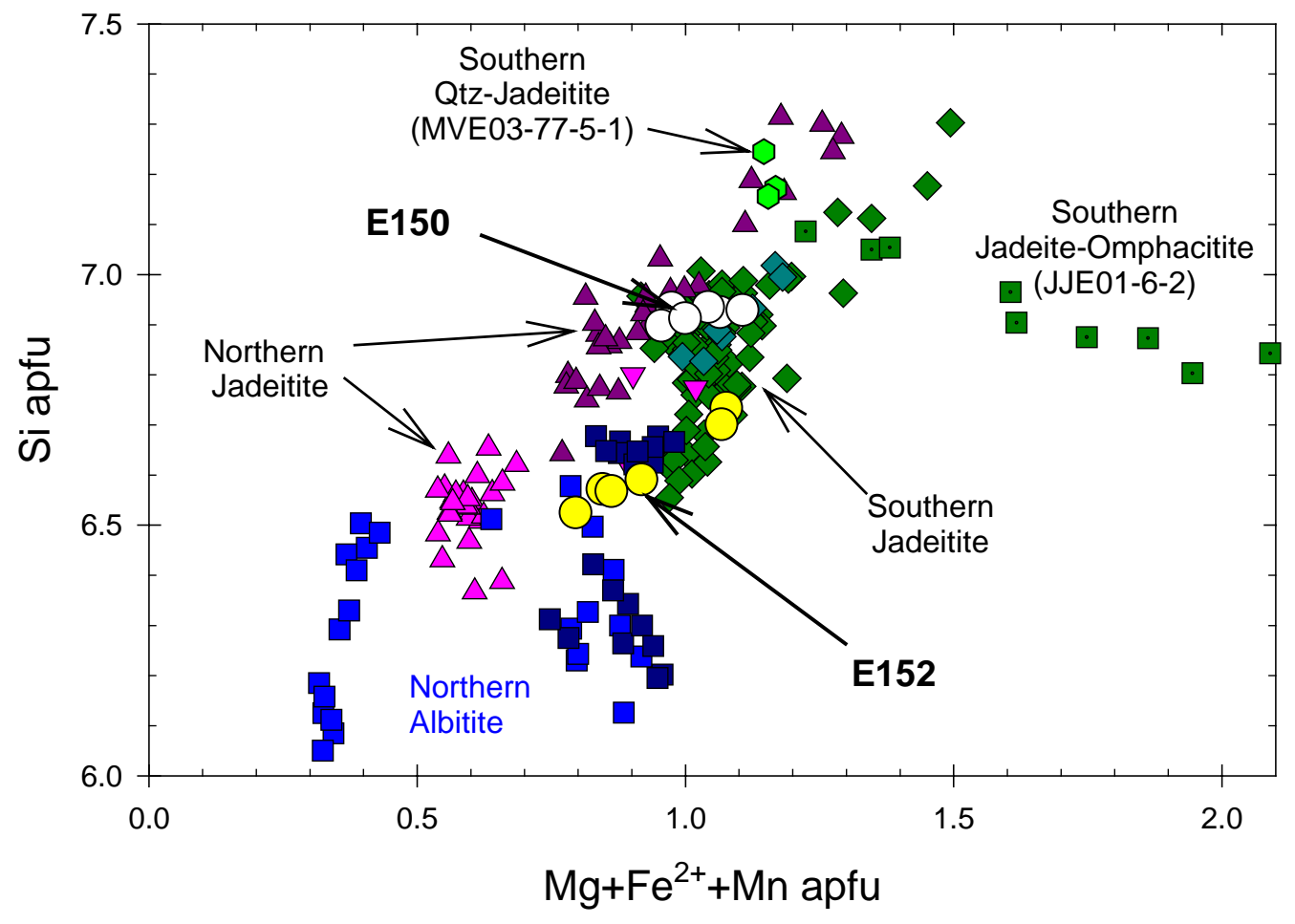


Figure 6a

\section{Jadeitite - North of MFZ}

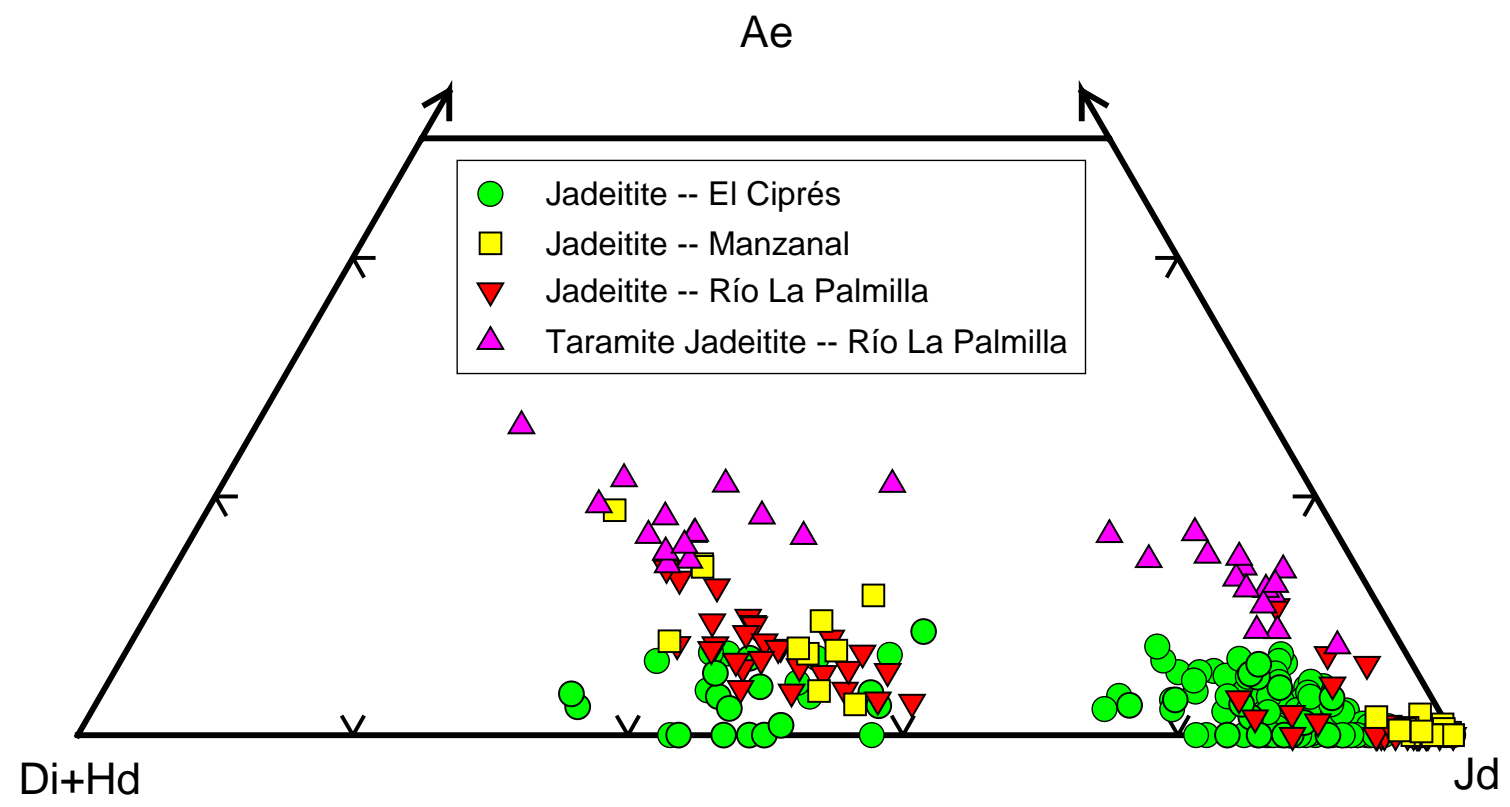

Figure $6 \mathrm{~b}$

\section{Jadeitite -- South of the MFZ}

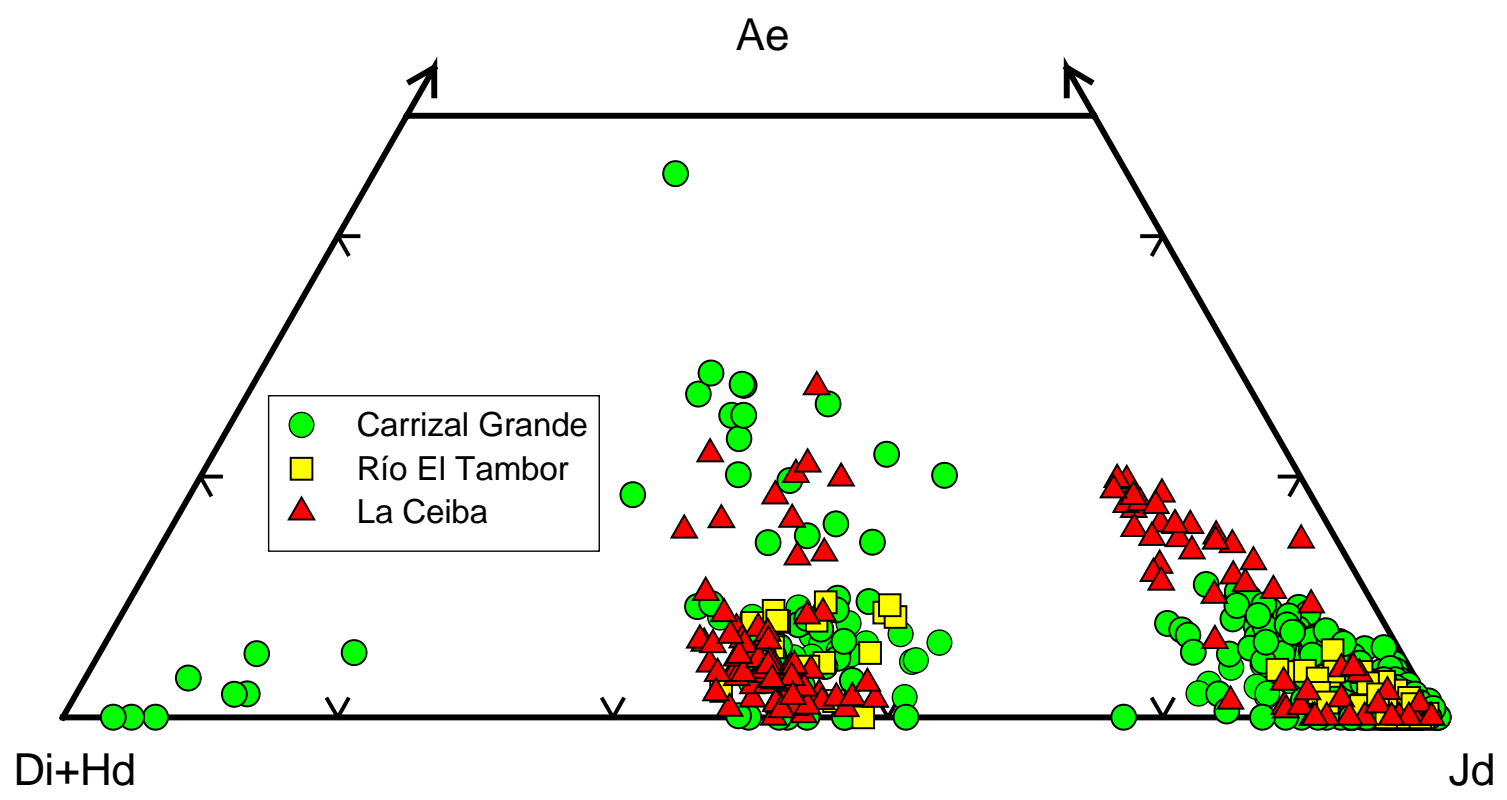


Figure 6c

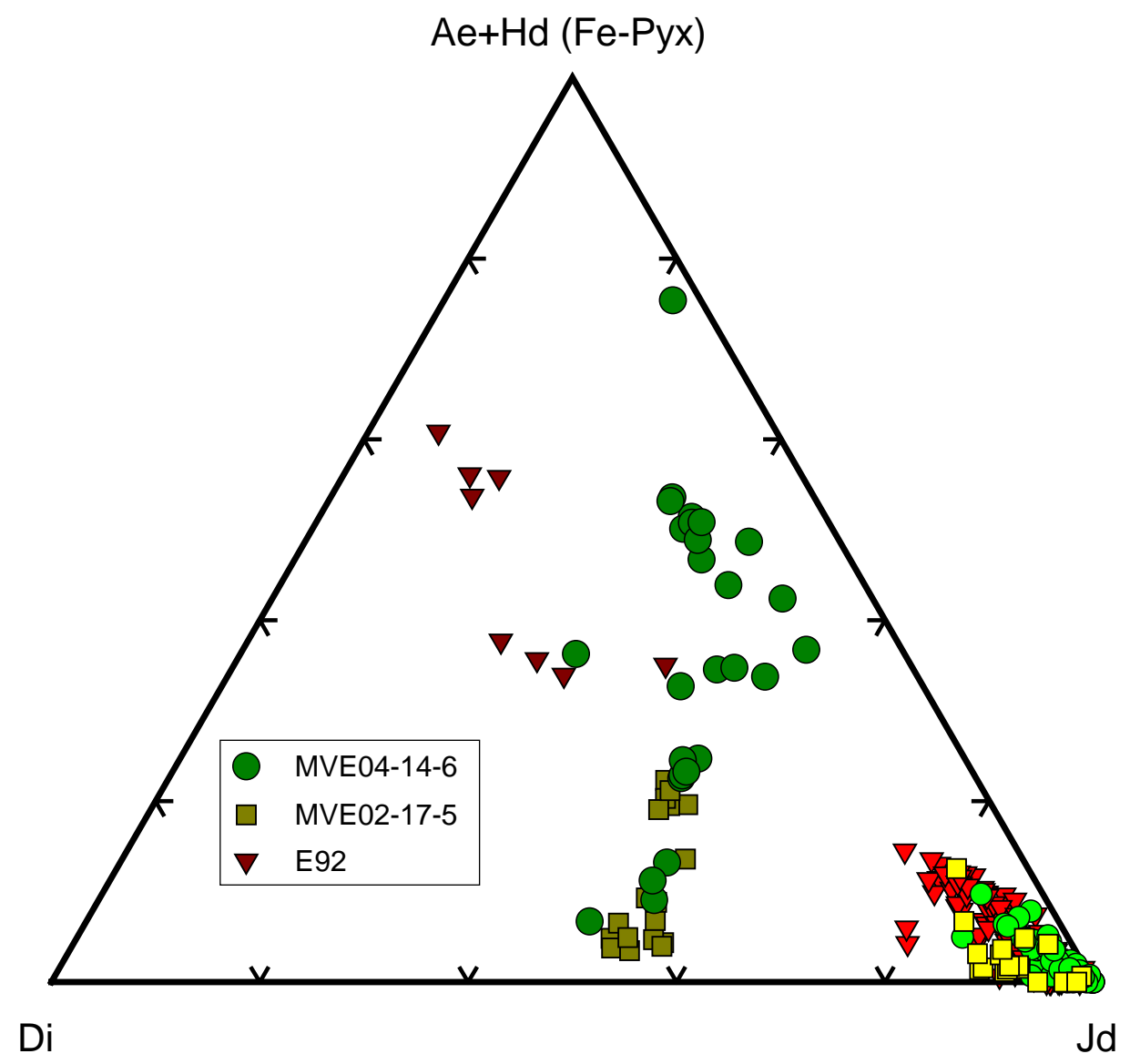



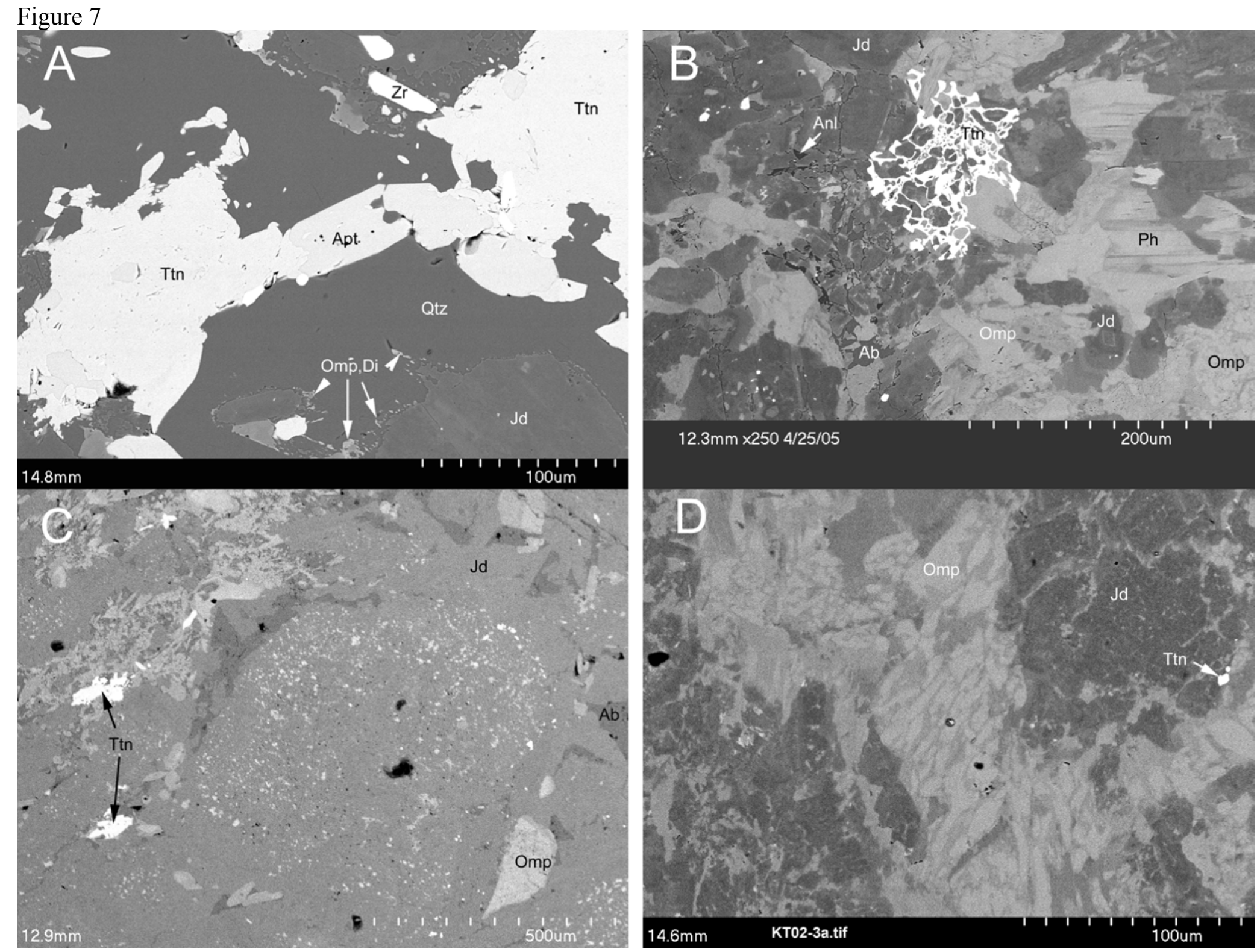
Figure 8

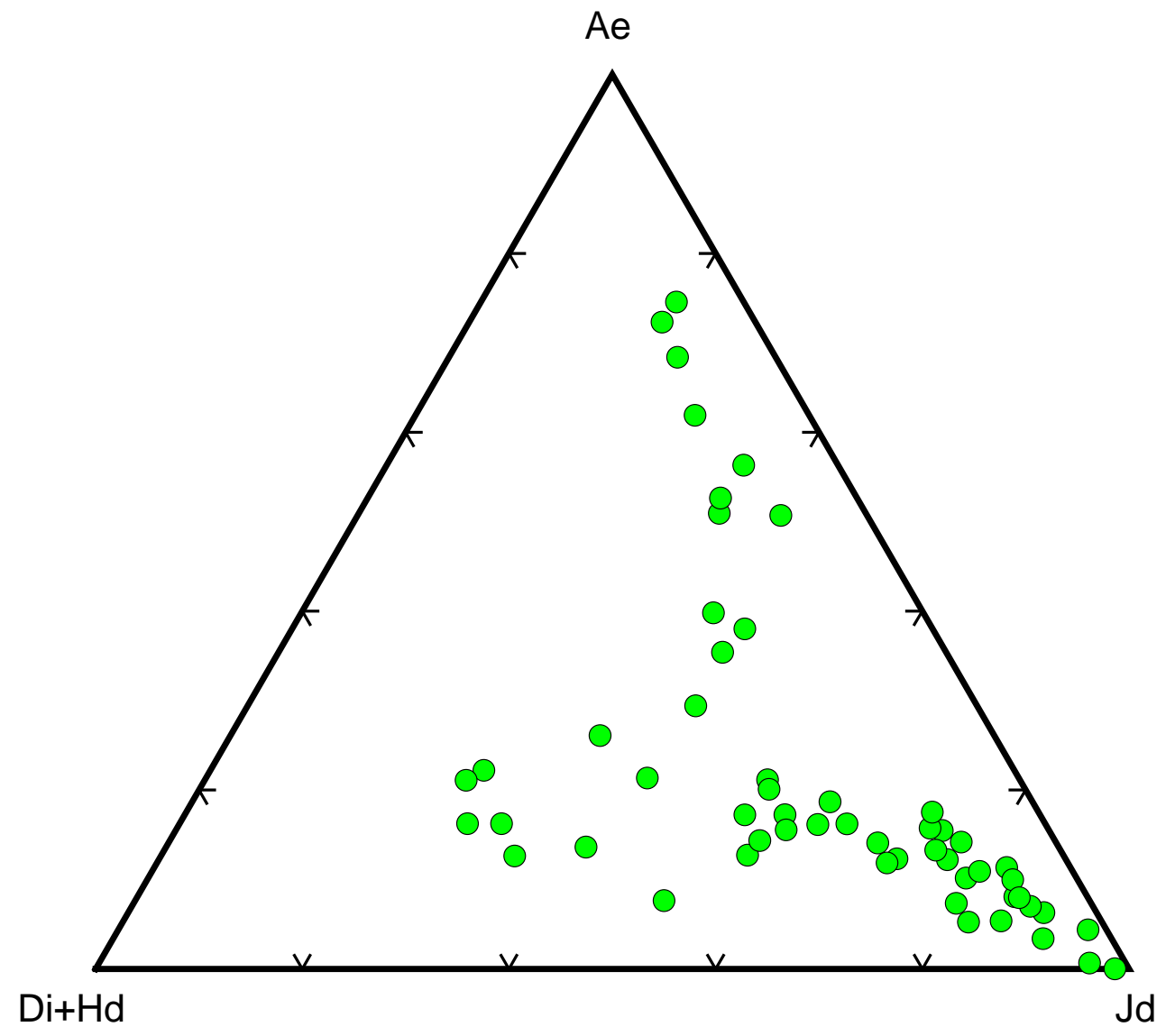

